\title{
UNDISSOLVED URANIUM ALUMINIDE IN REPROCESSING OF TEST REACTOR FUELS
}

By

B. E. Paige

M. E. Jacobson

T. L. Evans

V. H. Barnes

\section{IDAHO NUCLEAR CORPORATION}

A Jointly Owned Subsidiary of

AEROJET GENERAL CORPORATION

ALLIED CHEMICAL CORPORATION

PHILLIPS PETROLEUM COMPANY

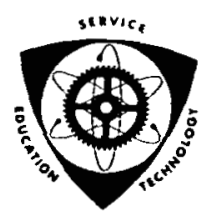

U. S. Atomic Energy Commission Scientific and Technical Report

Issued Under Contract AT(10-1)-1230

Idaho Operations Office 


\section{DISCLAIMER}

This report was prepared as an account of work sponsored by an agency of the United States Government. Neither the United States Government nor any agency Thereof, nor any of their employees, makes any warranty, express or implied, or assumes any legal liability or responsibility for the accuracy, completeness, or usefulness of any information, apparatus, product, or process disclosed, or represents that its use would not infringe privately owned rights. Reference herein to any specific commercial product, process, or service by trade name, trademark, manufacturer, or otherwise does not necessarily constitute or imply its endorsement, recommendation, or favoring by the United States Government or any agency thereof. The views and opinions of authors expressed herein do not necessarily state or reflect those of the United States Government or any agency thereof. 


\section{DISCLAIMER}

Portions of this document may be illegible in electronic image products. Images are produced from the best available original document. 
ABSTRACT

During the dissolution of newer uranium-aluminum alloy fuels, uranium dissolved more slowly than aluminum. This study showed that the elutriation of uranium-aluminide particles from a continuous dissolver can be experienced. The effects of irradiation, the fuel fabrication method (wrought alloys vs powder metallurgy), and dissolver operating conditions upon this phenomenon were determined. The dissolution rates and the shapes and sizes of such particles were compared. Recommendations for procedures to insure complete dissolution of uranium during chemical reprocessing of uranium-aluminum fuels are made. 


\section{SUMMARY}

During the reprocessing of uranium-aluminum alloy fuel, elements are dissolved in nitric acid using mercury as catalyst. Complete dissolution of the uranium must be assured when highly enriched fuel is being processed. The current studies have shown that the dissolution rates of uranium aluminide and aluminum differ sufficiently to permit undissolved fuel particles from unirradiated test reactor fuel to elutriate from a continuous dissolver. Particles elutriated from fuel fabricated by the powder metallurgical method dissolved more slowly than fuel particles from wrought alloy fuel. The metallurgical origin of the fuel did not affect the fraction of uranium elutriated from a small dissolver with short residence time, but the quantity of undissolved uranium elutriated was greater for fuels with higher uranium content. The dissolution rates, the sizes, and the shapes of the elutriated particles were determined. The fuel particles in the powder metallurgical fuel are somewhat larger, but the difference in dissolution rate was only partially due to this factor. Undissolved uranium aluminide from fully irradiated test reactor fuel did not have a crystalline $\mathrm{X}$-ray pattern and dissolved more rapidly than unirradiated particles from the same type of fuel.

The dissolution rate of uranium aluminide particles is most effectively increased by increasing the temperature of the dissolver product solution. Addition of a dissolver product from zirconiumuranium fuel containing $1 \mathrm{M}$ zirconium, 2.5M hydrogen ion, and $6.5 \mathrm{M}$ fluoride results in rapid dissolution of fuel particles. Mercury is not required for the dissolution of uranium aluminide in nitric acid, and it only slightly increases the rate. Concentrated nitric acid is the best reagent for dissolving uranium aluminide; 3M sodium hydroxide does not dissolve the particles. In most respects, the uranium aluminide resembles uranium metal rather than aluminum metal in dissolution characteristics. A number of additives (cations, anions, oxidants, complexers) were examined, but none was found to increase the dissolution rate of uranium aluminide in aluminum dissolver product solution.

During the dissolution of uranium-aluminum alloy fuel at ICPP, the quantity of undissolved solids can be minimized by operating the dissolvers so as to provide maximum residence time and maintaining solutions at as high a temperature as possible until the dissolution is complete. Dissolution can be completed in the dissolver product collection tank by heating to near the boiling point and agitating for a period of one to two hours. 
ABSTRACT . . . . . . . . . . . . . . . . . . . . ii

SUMMARY. . . . . . . . . . . . . . . . . . . . . . iii

I. INTRODUCTION . . . . . . . . . . . . . . . . . . . I

II. CONTINUOUS DISSOLVERS AND SOLIDS COLLECTION SYSTEMS. • • . . • 3

1. EQUTPMENT USED FOR UNIRRADIATED FUELS. . . . . . . . . . 3

2. EQUIPMENT USED FOR IRRADIATED FUELS. . . . . . . . . . 5

III. RESULTS AND DISCUSSION . . . . . . . . . . . . . . 7

1. DISSOLUTION OF FUEL AND COLLECTION OF SOLIDS FROM

UNIRRADIATED FUEL. • • • • • • • • • • • • • • • • • 7

1.I Description of Fuels Studied. . . . . . . . . . 7

1.2 Dissolution of Unirradiated Fuel. . . . . . . 8

1.3 Description of Solids Collected from ETR Fuels. . . 8

1.4 Dissolution of Solids from ETR Fuels. . . . . . . 12

2. DISSOLUTION OF FUEL AND COLLECTION OF SOLIDS FROM

IRRADIATED FUEL. . . . . . . . . . . . . . . . . 14

2.1 Description of Irradiated Fuel. . . . . . . . . 14

2.2 Dissolution of Irradiated Fuel. . . . . . . . . 14

2.3 Description of Solids from Irradiated Fuel. . . . . 14

3. DISSOLUTION OF URANIUM ALUMINIDE POWDER. . . . . . . . 16

3.1 Effect of Particle Size............. . I6

3.2 Dissolution in Process Solutions and Reagents . . . 16

IV. CONCLUSIONS. . . . . . . . . . . . . . . . . . . . 19

V. RECOMMENDATIONS FOR OPERATION OF ICPP. . . . . . . . . . . 21

VI. REFERENCES . . . . . . . . . . . . . . . . . . . 22 APPEINDIX A - CONTINUOUS DISSOLVER OPERATION. • . • • • • • • • • 23

1. OPERATION OF MODEL I DISSOLVER . . . . . . . . . . 25

2. COMPARISON OF MODEL 1 AND MODEL 2 DISSOLVERS . . . . . . 29 
APPEINDIX B - COMPARISON OF COLLECTION SYSTEMS AND SOLIDS . . . . 31

l. COMPARISON OF SOLIDS . . . . . . . . . . . . 33

I.I Centrifugation of Solids. . . . . . . . . 33

1.2 Settling of the Solids. . . . . . . . . . 33

1.3 Comparison of Centrifugation and Settling . . . . 35

2. SOLIDS FROM IRRADIATED FUEL. . . . . . . . . . 36

APPENDIX C - DISSOLUTION OF URANIUM ALUMINIDE. . . . . . . . 39

1. DISSOLUTION OF URANIUM ALUMINIDE ELUTRIATED FROM 41

ETR FUEL . • . . . . • . . . . . . . . . . . . . . .

1.1 Effect of Temperature ............. 41

1.2 Effect of Particle Size............ 41

2. DISSOLUTION OF URANIUM ALUMINIDE POWDER. . . . . . . . . 4 I

2.1 Reagents for Dissolution. . . . . . . . . . 44

2.2 Effect of Additives............. 44

FIGURES

1. Continuous dissolver Model 1 used for unirradiated fuel . . . 4

2. Continuous dissolver Model 2 used for irradiated fuel . . . . 6

3. Uranium aluminide particles used to fabricate powder

metallurgical fuel $\left(\mathrm{COM}-\mathrm{UA} \mathrm{I}_{\mathrm{X}}\right)$. . . . . . . . . . . 10

4. Solids elutriated from the dissolution of powder metallurgical

fuel (ETR-AI) . . . . . . . . . . . . . . . II

5. Solids elutriated from dissolution of wrought alloy fuel

(ETR-Syl) . .................. 11

6. Effect of temperature on uranium aluminide dissolution. . . 12

7. Extended dissolution of solids from ETR fuel at $30^{\circ} \mathrm{C}$. . . . 13

8. Effect of particle size on dissolution of uranium aluminide .17

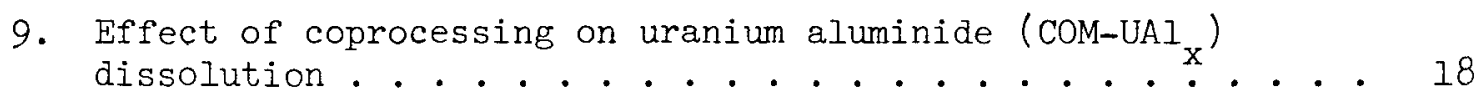


A-1. Diagram of continuous dissolver, Model 1. . . . . . . 26

A-2. Effect of acid feed rate on aluminum dissolution. . . . . 27

A-3. Effect of mercury concentration on aluminum dissolution . . 28

A-4. Residual ETR fuel from continuous dissolver . . . . . . 28

A-5. Diagram of hot cell equipment . . . . . . . . . . 30

B-1. Continuous centrifuge used to collect elutriated solids . . 34

B-2. Diagram of centrifuge and skimmer . . . . . . . . . 34

B-3. Fuel pieces elutriated from the continuous dissolver. . . . 35

B-4. Settling vessel used to collect elutriated solids . . . . 35

C-1. Dissolution of COM-UAI ${ }_{\mathrm{X}}$ powder. . . . . . . . . . . 42

C-2. Dissolution of elutriated solids from ETR-AI fuel . . . . . 42

C-3. Dissolution of elutriated solids from ETR-Syl fuel. . . . 43

C-4. Dissolution of elutriated solids from ETR-B\&W fuel. . . . . 43

C-5. Effect of nitric acid concentration on dissolution of 45

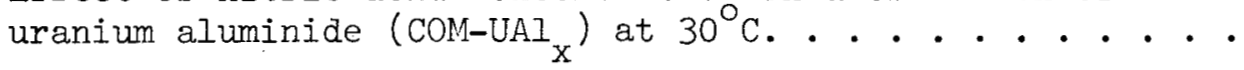

TABIES

I. Comparison of Dissolvers. . . . . . . . . . . . . 3

II. Relationship of Fuels Studied to ICPP Processing Schedules. 7

III. Description of Solids from Unirradiated ETR Fuel. . . . . . 9

IV. Comparison of Uranium Content of Fuels and Elutriated
Solids. . . . . . . . . . . . . . . 15

B-I. Comparison of Solids Collected by Different Systems from Unirradiated Fuel . . . . . . . . . . . . 36

C-I. Size Distribution of Uranium Aluminide Particles. . . . . . 44

C-II. Effect of Mercury on Dissolution of Uranium Aluminide at $60^{\circ}$ C...................... 45

C-III. Dissolution of Uranium Aluminide with Alkaline Oxidants . . 46

C-IV. Effect of Chemical Additives on Dissolution of Uranium Aluminide . . . . . . . . . . . . . . . . . . 
UNDISSOLVED URANIUM ALUMINIDE IN

REPROCESSIING OF TEST REACTOR FUELS

\section{INTRODUCTION}

Complete dissolution of uranium must be assured both from the standpoint of criticality and from the standpoint of uranium input accountability because highly enriched uranium is reprocessed at the Idaho Chemical Processing Plant (ICPP). In early studies of the continuous dissolution of uranium-aluminum alloys at ICPP, no evidence of preferential dissolution of aluminum was noted. Since these first studies were made, however, uranium content has increased in test reactor fuel plates, and fuels containing higher percentages of uranium in the core alloy are being processed 三t ICPP. Recent dissolution data(I) for aluminum-uranium alloys containing 22 and $32 \mathrm{wt} \%$ uranium showed that uranium dissolved more slowly than aluminum in batch dissolutions of fuel prepared by wrought alloy techniques; therefore, extensive studies were undertaken to determine if dissolution of uranium is complete during continuous dissolution of the alloys. Simultaneously with these studies, some difficulties were encountered at ICPP with solids in the transfer lines adjacent to the dissolver; the first of the powder metallurgical fuel was being processed at that time, and so particular attention has been given to the metallurgical origin of the fuel in this study. Fuel prepared by powder metallurgical techniques has larger uranium-aluminide particles in the core than wrought alloy fuel $(2)$; therefore, the dissolution of uranium in the powder metallurgical fuel may be even slower than for the wrought alloy fuel originally studied.

Uranium-aluminum alloys used in the cores of test reactor fuels are being fabricated by two different metallurgical methods. In the wrought alloy method, the uranium and aluminum are melted and cast resulting in a dispersion of uranium aluminide (primarily $\mathrm{UAl}_{4}$ ) in an aluminum matrix. Cores prepared by the powder metallurgicaI method are made by compacting aluminum powder and uranium aluminide powder (primarily $\mathrm{UAl}_{3}$ ) with particle sizes larger than those produced by the wrought alloy method. In the same reactor, the ETR for example, the fuel clad and side plates are essentially the same for both fuels, and only the core differs so that the dissolution of the bulk of the aluminum in the fuel is identical.

All uranium-aluminum alloy fuel is dissolved at ICPP in a continuous dissolver in which the nitric acid is fed continuously into the bottom of the dissolver, fuel is charged semi-continuously, and the dissolver product is discharged from the upper portion of the dissolver. The small continuous dissolver used for these experiments permitted the use of small quantities of actual fuel for the dissolutions; however, the shorter residence time resulting from the shorter dissolver height prevents direct correlation of the quantity of undissolved uranium elutriated with that elutriated from the plant dissolver.

The current study was designed to determine if the difference in dissolution rate between the fuel particles and aluminum matrix differs 
sufficiently to permit undissolved fuel particles to elutriate from a continuous dissolver. In batch dissolutions, the undissolved fuel particles from the core remain in contact with the solution and continue to dissolve. In continuous dissolution, the solution leaves the dissolver as the fuel dissolution progresses. In order to stop further dissolution of undissolved uranium as soon as possible after the solution left the dissolver, solids elutriated from unirradiated fuel were collected in a continuous centrifuge. The properties of collected solids were determined and compared for fuels with different metallurgical origin.

After it was established that fuel particles were elutriated from unirradiated fuel, fully irradiated fuel was dissolved and solids examined to see if irradiation had changed the structure sufficiently to prevent elutriation of the fuel particles. In order to simplify the equipment for irradiated fuel, the solution was cooled and solids were collected by settling. Unirradiated fuel was dissolved in the same equipment to evaluate the effect of the different collection method. Some of the uranium fuel particles did dissolve during collection; this data was used to evaluate the dissolution rate of the unirradiated fuel particles.

Since uranium aluminide was elutriated from the continuous dissolvers, information was obtained on the dissolution characteristics so that ICPP operating procedures can be modified to assure complete dissolution of uranium aluminide fuel particles. Fuel particles elutriated from the continuous dissolver were compared to the uranium aluminide used to fabricate powder metallurgical fuel. Rate of disappearance of uranium from dissolver product solutions was determined for all types of elutriated fuel particles at $30,60,80$, and $100^{\circ} \mathrm{C}$. The effects of various process conditions and reagents were determined. Means of increasing the rate of dissolution of the uranium aluminide were explored. Recommendations for operation during the reprocessing of uranium-aluminum fuel have been made from this data. 


\section{CONTINUOUS DISSOLVERS AND SOLIDS COLLECTION SYSTEMS}

\section{EQUIPMEIVT USED FOR UNIRRADIATED FUELS}

A continuous dissolver, 3/4 inch inside diameter and 19 inches high, was built in the Chemical Technology laboratory and operated to dissolve the aluminum fuel. This small dissolver is especially suited to the dissolution of uranium-bearing fuel which can be obtained only in small quantities; three ETR fuel plates (containing 80 grams of uranium-235) cut into 3/8-inch strips will supply feed for this dissolver for six hours of continuous operation. Figure 1 is a photo of the Model 1 dissolver. A complete description and a discussion of the operation and control of this unique short dissolver is given in Appendix A. As shown in Table $I$, the dimensions and operating conditions were scaled to the ICPP continuous dissolver for aluminum fuel in all. respects except dissolver height. ICPP dissolver is 13 times taller than the small dissolver, and the residence time is correspondingly longer. However, the residence time in the plant dissolver may be less than four minutes if the ratio of the hold-up volume to the dissolver volume is the same as that of the small dissolver. The velocity of the dissolver solution through the small dissolver was the same as in the plant dissolver, a very important factor in the elutriation of solids.

TABLE I.

COMPARISON OF DISSOLVERS

ICPP Dissolver (ETR Coprocess)

Length

Diameter

Ratio L/D

Cross-Section Area

Velocity (Flowrate/Area)

Al Dissolution Rate

Dissolver Volume

Liquid Hold-Up

Estimated Residence Time
$15 \mathrm{ft}$

7 in ID

26

40 in $^{2}$

$5.61 / \mathrm{in}^{2}-\mathrm{hr}$

$4.8 \mathrm{KgAl} / \mathrm{in}^{2}$-day

1401

Unknown

$4 \mathrm{~min}$

\section{Glass Dissolver}

19 in

0.75 in ID

26

0.44 in $^{2}$

$6.01 / \mathrm{in}^{2}-\mathrm{hr}$

$4.8 \mathrm{KgAl} / \mathrm{in}^{2}$-day

$135 \mathrm{ml}$

$<10 \mathrm{ml}$

$15 \mathrm{sec}$

A continuous centrifuge was operated at 1000 times the force of gravity in conjunction with the Model 1 dissolver in order to collect the elutriated solids immediately after the solution was discharged from the dissolver, thus minumizing further dissolution of the solids. The laboratory basket centrifuge, described in Appendix B, was operated similarly to the centrifuge installed at ICPP. In continuous operation, the dissolver product is introduced through a plastic tube to the bottom of the centrifuge, and the supernatant liquid overflows the top lip of the bowl into the draining chamber. At a feed rate of $45 \mathrm{ml} / \mathrm{min}$, the 


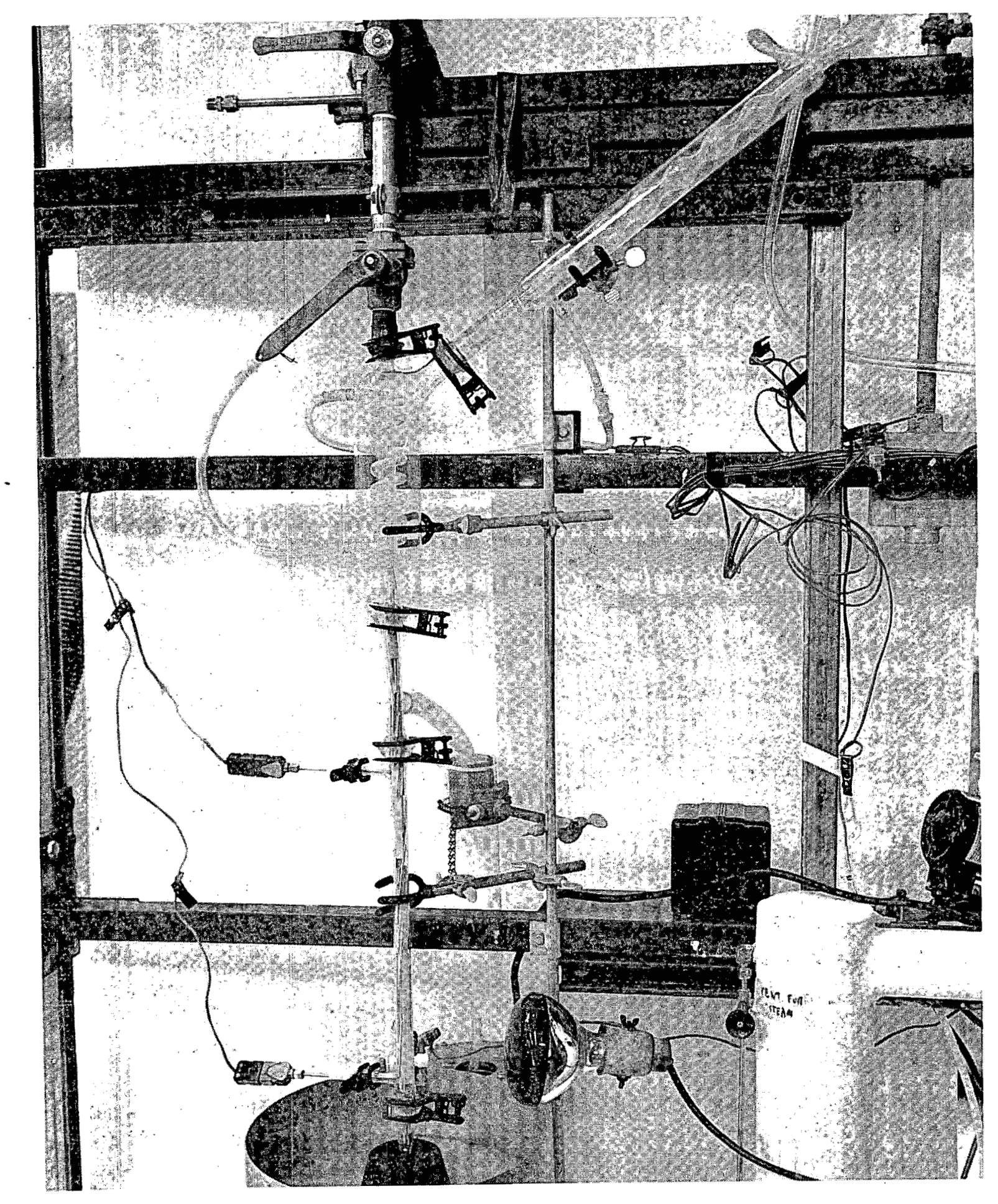

Figure 1. Continuous dissolver Model 1 used for unirradiated fuel. 
residence time is about six.minutes compared to an estimated residence time of five minutes in the plant centrifuge. A hand operated skimmer was developed to remove the residual supernatant liquid from the solids at the completion of each dissolver run.

\section{EQUIPMENT USED FOR IRRADIATED FUELS}

The Model 2 continuous dissolver designed and constructed for the dissolution of irradiated fuels in the hot cell was the same as the continuous dissolver described above in every respect except the fuel charging system and the off-gas condenser. As shown in Figure 2, a much larger condensing area was afforded so that the fuel could be charged directly into the top of the dissolver without manipulating the ball valves used in the charger for the unirradiated fuel. A diagram of the hot cell equipment and a description of its operation is given in Appendix A.

In order to simplify the equipment in the hot cell, the solids were collected by a settling technique. The rate of dissolution of the elutriated particles in the dissolver product was greatly reduced by cooling the solution to $22^{\circ} \mathrm{C}$ in the cooling coil which can be seen in Figure 2. The dissolver product was then collected in the conical bottom of a 20-liter glass vessel. The solution was permitted to stand 18 hours after the vessel was filled to permit particles with $>2 \mu$ diameter and $6 \mathrm{gm} / \mathrm{cm}^{3}$ density to settle from the solution. A detailed description of the solids collection system, and a comparison of the efficiency of the settling system with the efficiency of the continuous centrifuge is given in Appendix $B$. 


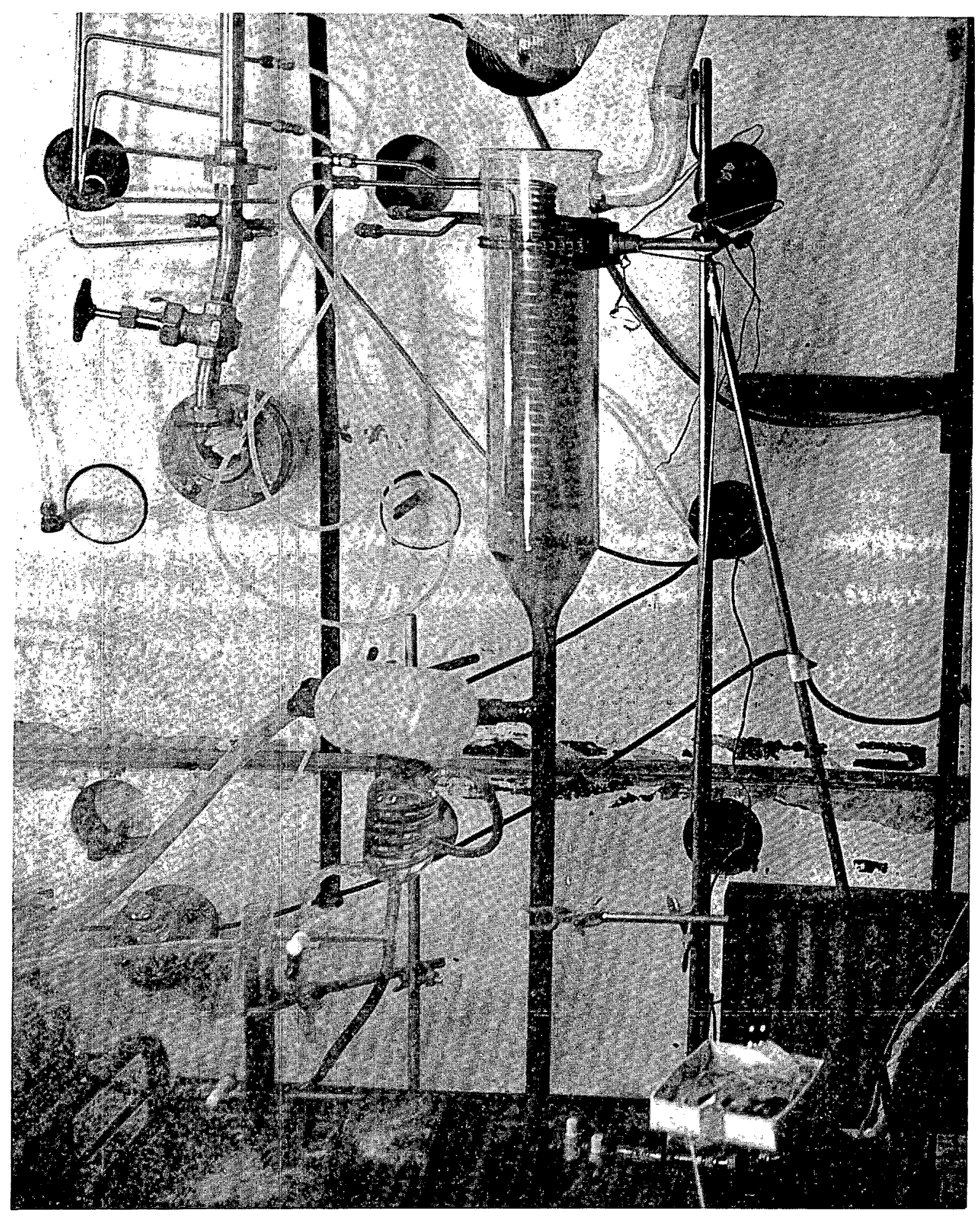

Figure 2. Continuous dissolver, Model 2 used for irradiated fuel. 


\section{RESULTS AND DISCUSSION}

For discussion, these studies have been divided into three parts. In the first part, actual tést reactor fuel plates fabricated by different metallurgical techniques were dissolved in a small continuous dissolver, and undissolved uranium fuel particles were found. The effect of various conditions upon the dissolution rate of the solids collected from unirradiated fuel was studied. In the second part, fuel irradiated to about $38 \%$ burn-up was also dissolved, and solids were collected to determine if irradiation altered the uranium aluminide and changed its dissolution characteristics. In the third part, the effect of process solutions and conditions upon dissolution rates of uranium aluminide was determined, and chemical means of increasing the rate were examined.

\section{DISSOLUTION OF FUEL AND COLLECTION OF SOLIDS FROM UNIRRADIATED FUEL}

\subsection{Description of Fuels Studied}

Three unirradiated ETR fuel elements fabricated by different manufacturers and one unirradiated ATR element were used to determine if uranium aluminide could be elutriated from a continuous dissolver. The ETR fuels dissolved in this study included fuel plates from elements made by Babcock and Wilcox (referred to as ETR-B\&W) according to Contract C-263, fuel plates made by Atomics International (referred to as ETR-AI) according to Contract $\mathrm{C}-278 \mathrm{~A}$, and fuel plates from an element made by Sylcor (referred to as ETR-Syl) according to Contract C-225. The plates from ATR elements were made by Atomics International (referred to as ATR-AI) according to Contract C-264. The ETR-Syl element was fabricated by the wrought alloy technique originally used for all test reactor fuels. The ETR-B\&W, ETR-AI, and ATR-AI fuels were fabricated by the powder metallurgical method. All of the fuels studied either have been processed in the past or will be processed in the future at ICPP. Table II shows the number of each type of fuel element of concern to ICPP. The data show that the current trend is towards use of powder metallurgical fuel.

TABLE II.

RELATIONSHIP OF FUELS STUDIED TO ICPP PROCESSING SCHEDULES (Numbers of Fuel Elements)

\begin{tabular}{|c|c|c|c|c|c|c|c|}
\hline \multirow[b]{2}{*}{ Processing Schedule } & \multicolumn{3}{|c|}{ Wrought Alloy Core } & \multicolumn{3}{|c|}{ Powder Metallurgy Core } & \multirow[b]{2}{*}{ ATR } \\
\hline & MTR & $\begin{array}{c}\text { ETR \& } \\
\text { Controls } \\
\end{array}$ & $\begin{array}{l}E T R \\
B-F \circ i I\end{array}(a)$ & $M T R-B \& W$ & ETR-B\&W & ETR-AI & \\
\hline $\begin{array}{l}\text { Last Campaign } \\
(1967-68)\end{array}$ & 410 & 300 & 0 & 260 & 750 & 0 & 0 \\
\hline $\begin{array}{l}\text { Future } \\
\text { (On hand or ordere }\end{array}$ & 530 & 380 & 260 & 4 & 67 & 856 & 1560 \\
\hline
\end{tabular}

(a) Designated B-foil because boron is dispersed in a sheet of aluminum foil. 


\section{I.2 Dissolution of Unirradiated Fuel}

Dissolutions of unirradiated fuels were made in the Model 1 dissolver. In preliminary dissolutions, ETR-B\&W fuel produced solids containing only $\mathrm{UAl}_{4}$, but the solids from ETR-AI and ATR-AI contained both $\mathrm{UAl}_{3}$ and $\mathrm{UAl}_{4}$. Dissolver product concentrations varied considerably during these dissolutions and ranged from $I M$ acid deficient to $3 M$ acid. These data showed that uranium aluminide could be elutriated from a continuous dissolver over a wide range of acid concentrations.

In order to determine the conditions which would consistently produce a solution with ICPP product concentration, dissolutions were made using various feed rates and mercury concentrations. Due to the shorter height of the dissolver, a constant feed rate and constant fuel height in the dissolver were needed to obtain a direct relationship between the aluminum dissolution rate and the mercury concentration (see Appendix A). At an aluminum dissolution rate comparable to that of ICPP, shown in Table $I$, the unirradiated ETR fuels were very reactive, and mercury levels required were considerably lower than those used in ICPP flowsheets. Based on the preliminary studies, the ETR-B\&W fuel was dissolved for 15 hours continuously at steady state using 6.3M nitric acid and $0.0005 \mathrm{M}$ mercuric nitrate. The product was sampled and analyzed approximately every 2 l/ 2 hours. The average aluminum concentration was l.39M with a standard deviation of 0.06 ; the average acid concentration was $\overline{2} .06 \mathrm{M}$ with a standard deviation of 0.19 ; and the specific gravity was $1.30 \overline{0}$ with a standard deviation of 0.005 at $23^{\circ} \mathrm{C}$. The same conditions and mercury concentration produced similar product concentrations for unirradiated ETR-AI and ETR-Syl fuels.

\subsection{Description of Solids Collected from ETR Fuels}

The solids collected in the centrifuge from each of the three ETR fuels were washed, dried, and weighed. Table III describes the solids obtained. These data showed that up to $25 \mathrm{wt} \%$ of the uranium in the fuel could be elutriated from the small dissolver. An additional 3 wt of the uranium elutriated from the dissolver was dissolved in the centrifuge and found in the centrifuge supernate (see Appendix B). The quantity of uranium aluminide collected as fuel particles is greater for elements with higher original uranium content and correspondingly higher percent uranium in their core; thus, the problem of elutriation of uranium aluminide will become more severe as uranium content is increased in fuels from test reactors. The particles in the core of ETR-AI were mostly $\mathrm{UAl}_{3}$ with some $\mathrm{UAl}_{4}$ present as is currently specified for powder metallurgical fuel, whereas the ETR-B\&W contained only UAl 4 indicating that this early powder metallurgical fuel was somewhat different. The wrought alloy core in ETR-Syl contained mostly UAl 4 , but the presence of a small amount of $\mathrm{UAl}_{3}$ suggested that a small amount of silicon had been added to the core. In addition to the uranium aluminide fuel particles, the solids contained undissolved metal which was also elutriated from the dissolver. Small amounts of uranium dioxide were identified by $\mathrm{X}$-ray diffraction analyses in ETR-B\&W. 
TABLE III.

DESCRIPTION OF SOLIDS FROM UNIRRADIATED ETR FUEL

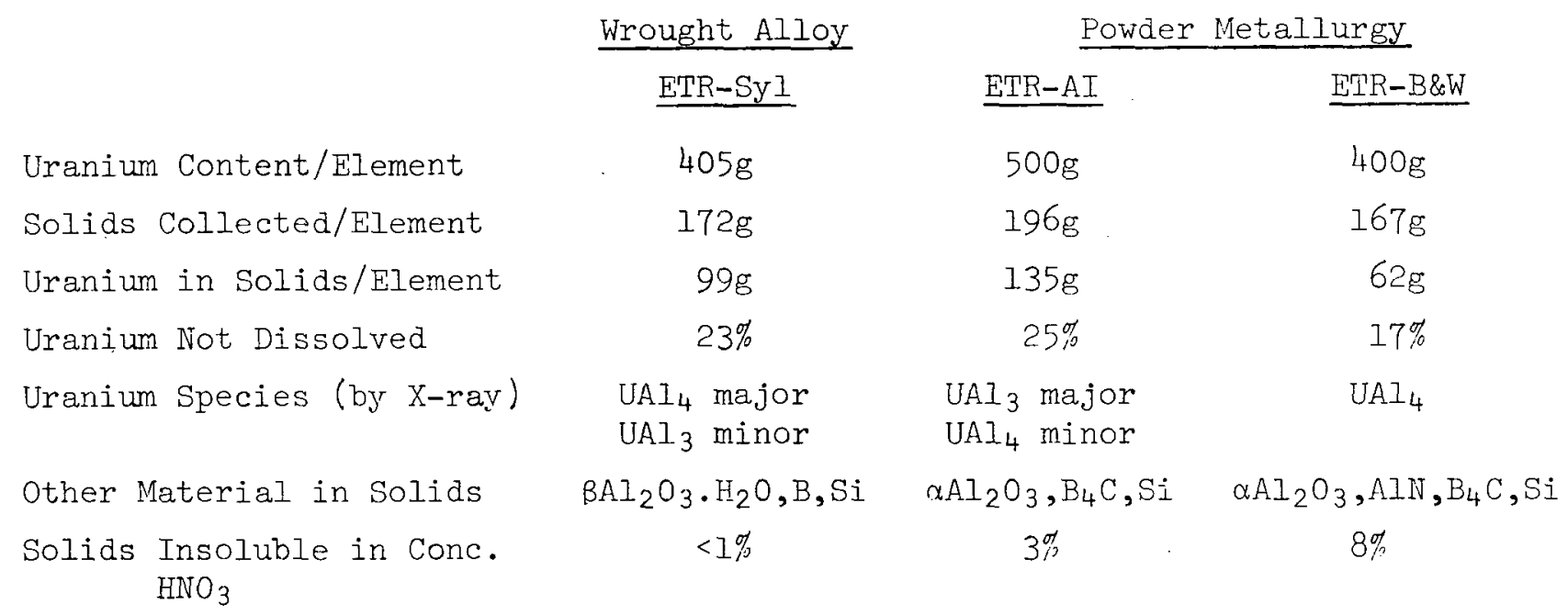

The method of fabrication did not affect the quantity of elutriated uranium aluminide particles. Micrographs of the two types of fuels 2 . show that there is a difference in particle size. In the wrought alloy, the large particles have an apparent diameter of 25 to $50 \mu$, while there are many small particles of only 0.2 to $2 \mu$. Large particles in powder metallurgical fuel are up to $150 \mu$, but less than $25 \mathrm{wt} \%$ are less than $44 \mu$ according to specifications ior this type of fuel. In the original fuel, a large amount of the total uranium is present as very small particles; however, the large particles will require a longer period of time to dissolve and are of particular concern with regard to undissolved uranium in process solutions. Dissolution data (see Section 3.2) showed that the difference in dissolution rates for particles collected from the two different types of fuels was not very great. The inability to detect the difference may have been alue to the large proportion of very small particles in the solids elutriated from the small dissolver.

The particles elutriated from the two types of fuels were examined for shape and size. Pure commercial uranium aluminide powder (COM-UAl ${ }_{x}$ ) used to fabricate powder metallurgical fuel, shown in Figure 3 , is large and particles are relatively spherical in shape. Figures 4 and 5 are photos of the collected solids after drying in air at room temperature. The solids elutriated from ETR-AI are similar in appearance to COM-UAI but much smaller due to partial dissolution. The solids from ETR-Syl, however, appear to be very irregular in shape and contain far more undissolved alloy pieces which are visible as platelets. The elutriated particles were sieved, but most were too small to determine size difference by this method (see Appendix C).

In addition to the uranium aluminide particles, the solids contained from 5 to 7 wt\% undissolved metal which had passed through the stainless steel screen on the dissolver product line (see Appendix B). The solids 
collected from the powder metallurgical fuels, ETR-AI and ETR-B\&W, contained 3 and 8 wt\%, respectively, of material which was not soluble in nitric acid. Materials found in the insoluble solids included silicon from the aluminum alloys, boron carbide added to the fuel core as a neutron poison, and $\alpha$-alumina which is an impurity produced during the fabrication of the cores; the ETR-B\&W also contained aluminum nitride. The solids elutriated from the dissolution of ETR-B\&W fuel formed a hard cake in the centrifuge which could not be reslurried easily as were solids from the other ETR fuels. The unusual amount of inert solids and their unusual nature probably contributed to the plugging in the transfer lines adjacent to the dissolver when large numbers of these ETR-B\&W elements were processed in the last campaign at ICPP.

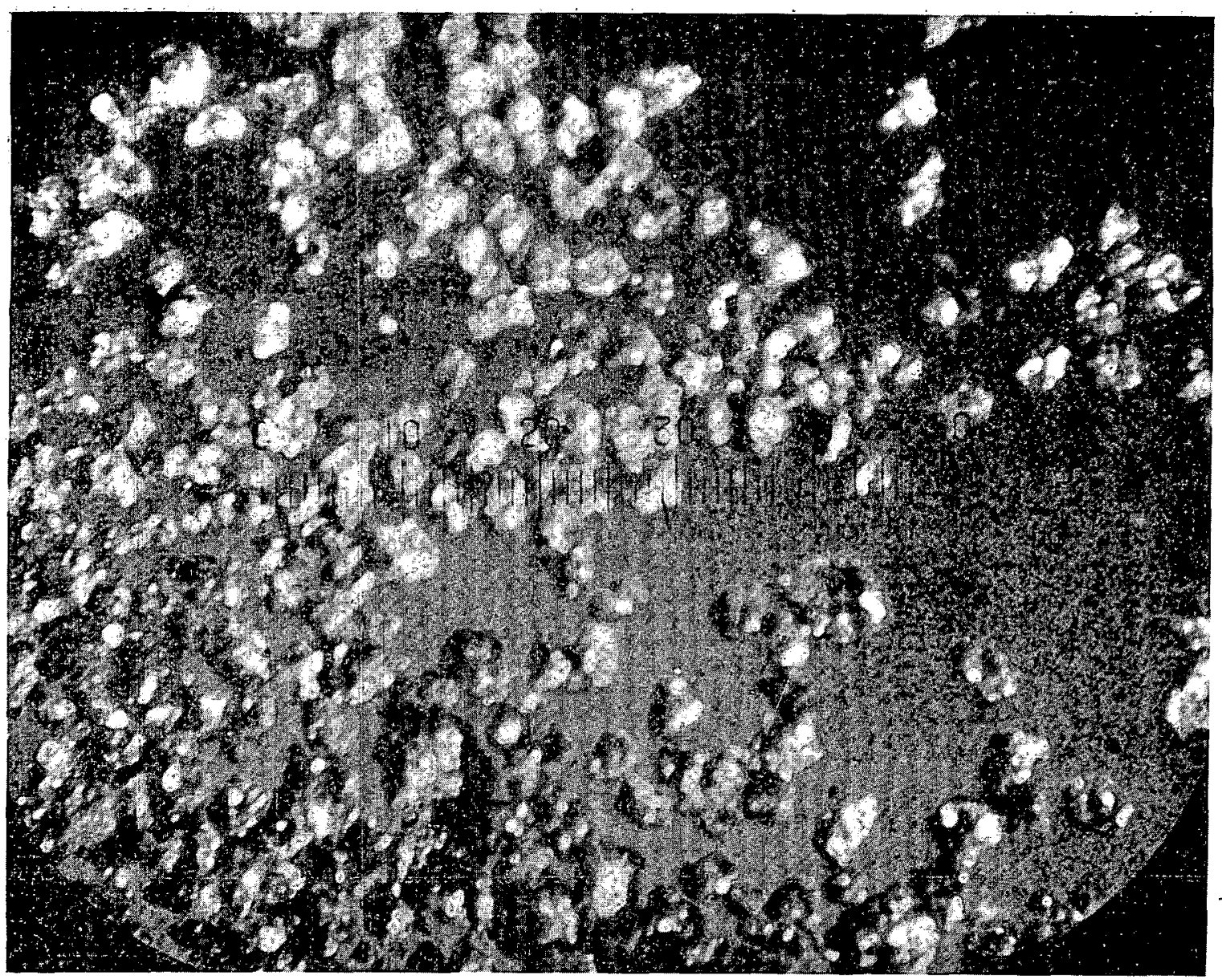

Figure 3. Uranium aluminide particles used to fabricate powder metallurgical fuel (COM-UAI ${ }_{\mathrm{X}}$ ). (50X magnification with $20 \mu$ per division). 


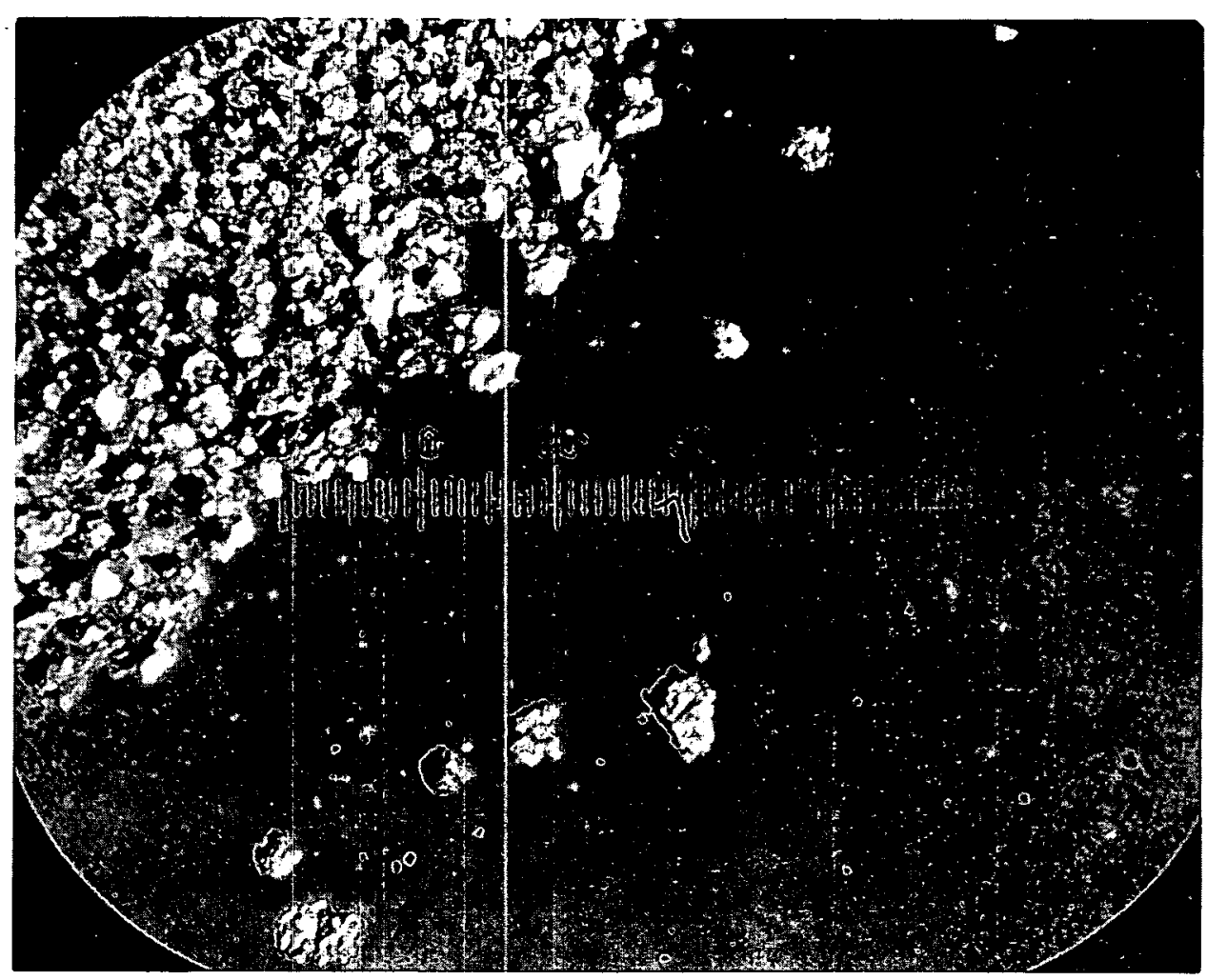

Figure 4. Solids elutriated from the dissolution of powder metallurgical fuel (ETR-AI). (50X magnification with $20 \mu$ per division).

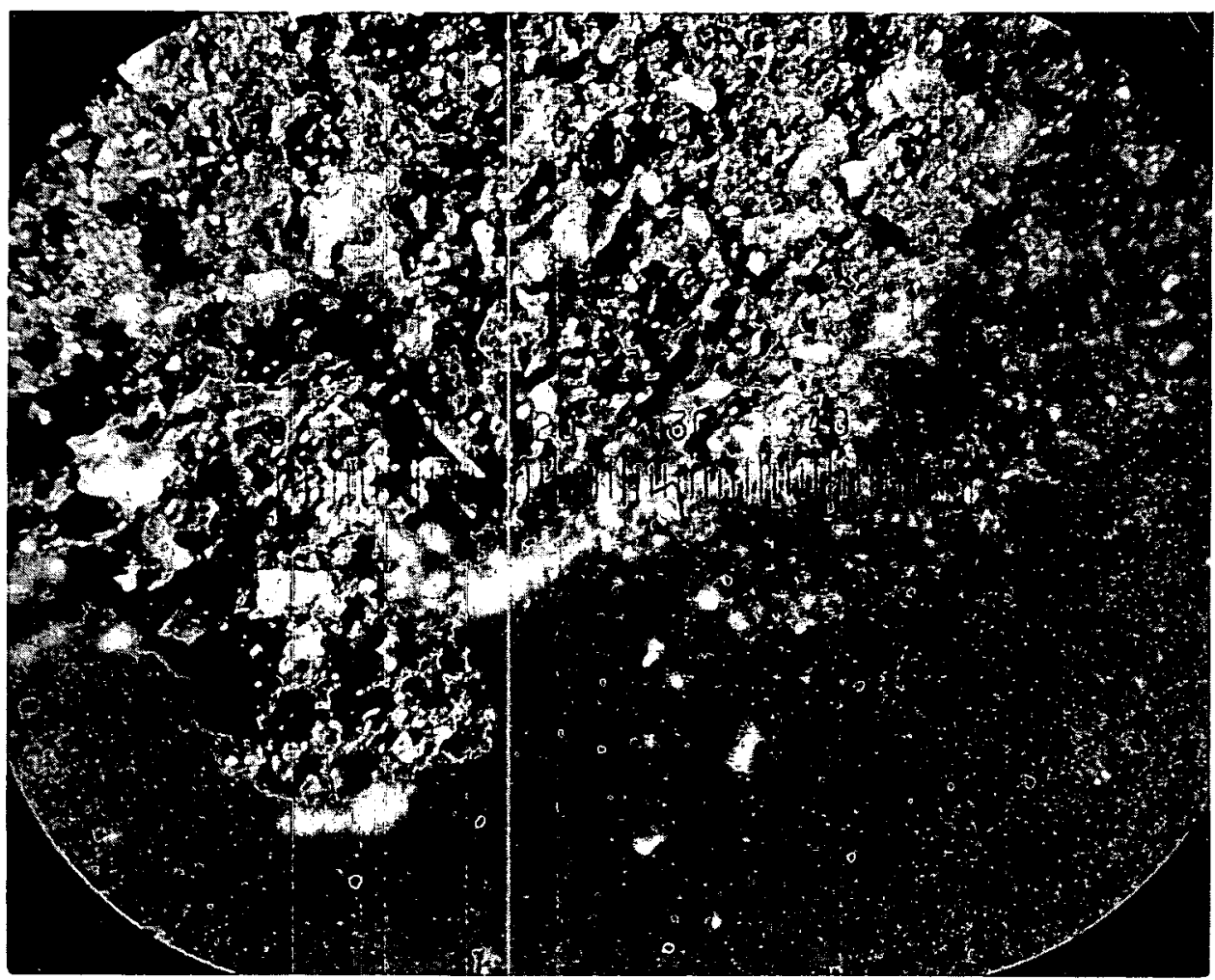

Figure 5. Solids elutriated from dissolution of wrought alloy fuel (ETR-Syl). (50X magnification with $20 \mu$ per division). 


\subsection{Dissolution of Solids from ETR Fuel}

The dissolution of uranium aluminide particles collected from the dissolution of the three ETR elements was studied in a dissolver product solution containing $1.5 \mathrm{M}$ aluminum nitrate, $1.5 \mathrm{M}$ nitric acid, and $0.007 \mathrm{M}$ mercuric nitrate. In addition, COM-UAl was dissolved for comparison. Details of the method and the rate curves obtained at 30,60 , 80 and $103^{\circ} \mathrm{C}$ are given in Appendix C. As shown in Figure 6 , the rate of dissolution increased considerably with the increase in temperature of the dissolver solution, and the dependance was similar for the different solids. The ETR-AI dissolution rate is about the same as that of the commercial uranium aluminide (COM-UAl $)$ used to fabricate test reactor fuels. Both contain more $\mathrm{UAI}_{3}$ than $\mathrm{UAI}_{4}$. ETR-SyI and ETR-B\&W fuels have very similar dissolution characteristics probably because the fuel particles in the ETR-B\&W resemble the alloy-type core and contain free aluminum in addition to the uranium aluminide. Both contain mostly $\mathrm{UAl}_{4}$. The dissolution data show that undissolved uranium aluminide particles can be completely dissolved in process by boiling 10 minutes when processing ETR-Syl or ETR-B\&W fuel and in 30 to 40 minutes for ETR-AI material. This latter should be the maximum time required for powder metallurgical fuel because the original uranium aluminide which has not been subjected to partial dissolution requires only 30 minutes.

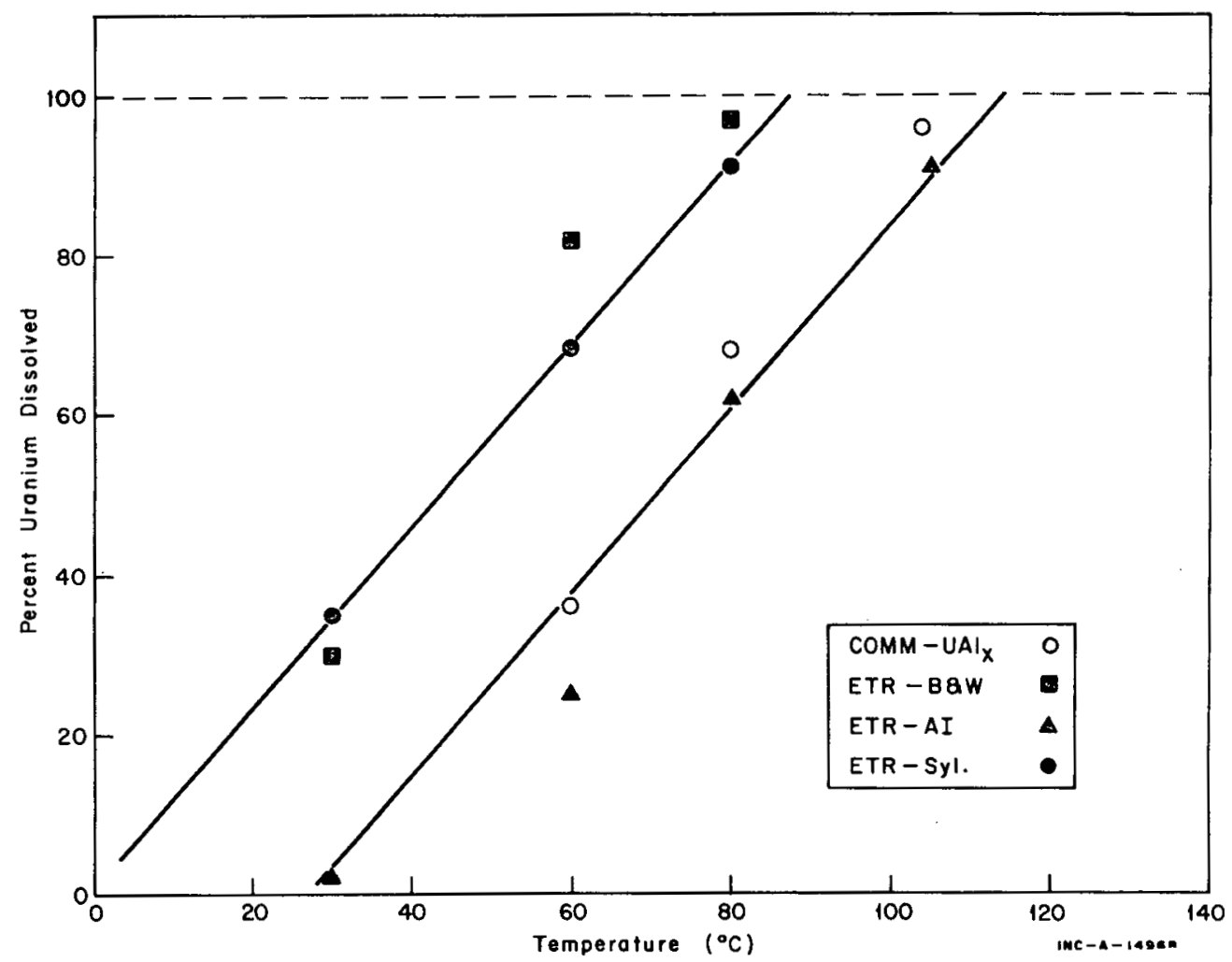

Pigure 6. Effect or temperature on uranium aluminide dissolution. 
The difference in rate of dissolution for the various solids collected from ETR fuel is especially evident in dissolutions extended to 22 hours at $30^{\circ} \mathrm{C}$, the operating temperature for dissolver product collection vessels in the past. The data in Figure 7 show that considerable time was required to dissolve fuel particles that may have been elutriated from the plant dissolver. The total time normally required to fill the receiving tank is about five hours, and two hours lapse between receipt of final dissolver product and transfer from the tank; at these conditions, the possibility of undissolved uranium solids still existing in the collection tank is greater for the ETR-AI fuel, the newer powder metallurgical core which will be processed in the next campaign, than for ETR-Syl fuel, the older wrought alloy core.

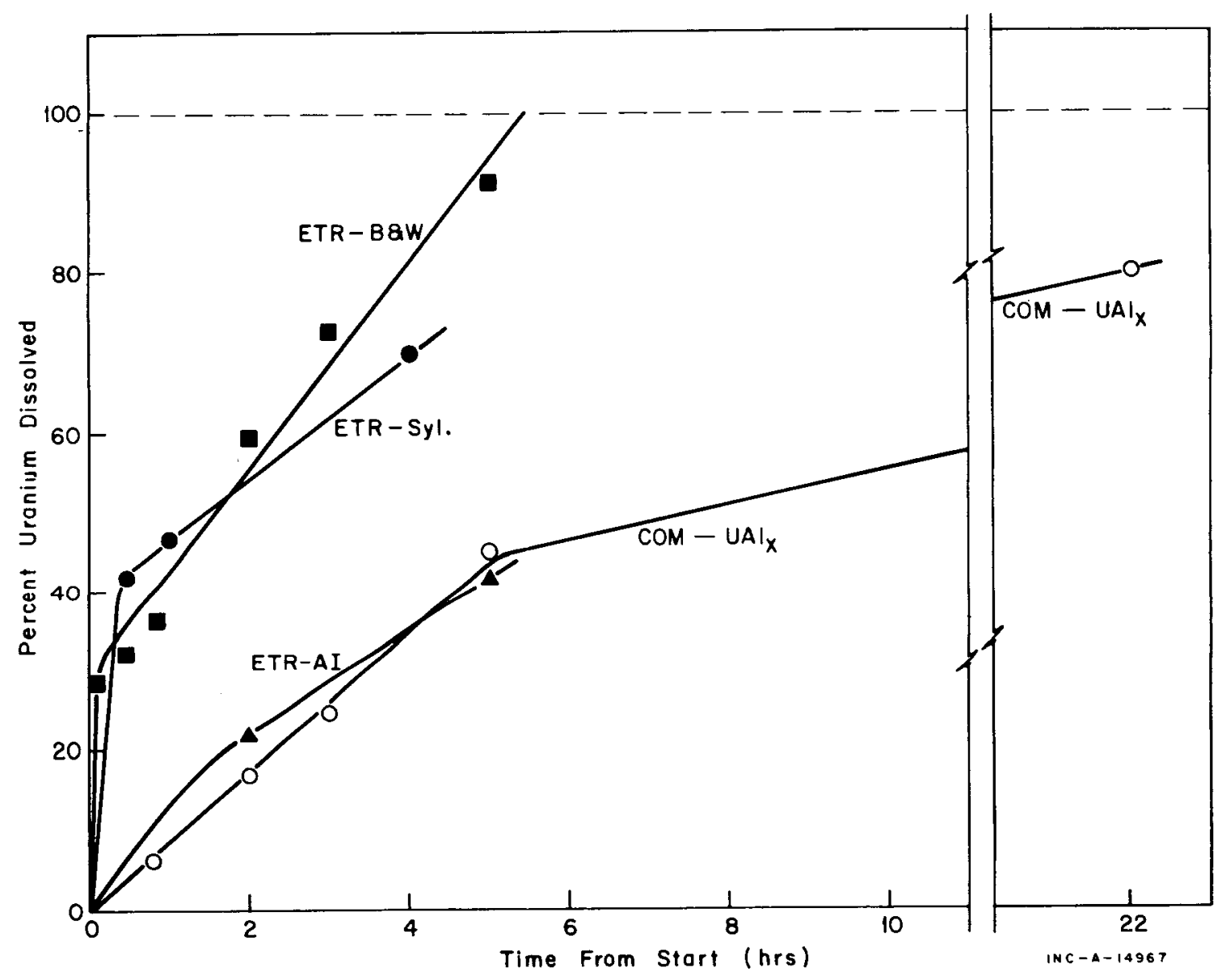

Figure 7. Extended dissolution of solids from ETR fuel at $30^{\circ} \mathrm{C}$. 
2. DISSOLUTION OF FUEL AND COLLECTION OF SOLIDS FROM IRRADIATED FUEL

Highly irradiated fuel was studied to learn if irradiation had altered the structure of the uranium aluminide sufficiently to change the dissolution characteristics so that the fuel particles would not elutriate from a continuous dissolver. Examination of irradiated core alloy ( 3 ) has shown that the irradiated uranium aluminide does not have a crystalline X-ray pattern. Photomicrographs, however, show the fuel particles as distinct entities even after irradiation. Irradiated fuel particles by themselves had not been examined previously.

\section{I Description of Irradiated Fuel}

Eight plates from fuel element E-186-E manufactured by Atomics International and irradiated in the ETR were used for these studies. The burn-up was calculated at $38 \%$ with $7.1 \times 10^{20}$ fissions per cc. In order to compare the two sets of equipment, preliminary dissolutions were made in the Hot Cell in the Model 2 dissolver with the settling vessel using the same unirradiated ETR=B\&W and ETR-AI fuels as were used in the Model 1 dissolver with the centrifuge. These data are discussed in detail in Appendix B.

\subsection{Dissolution of Irradiated Fuel}

Pieces of irradiated fuel cut 7/16 inch wide were dissolved in the Model 2 dissolver in the Hot Cell. As shown in Appendix A, the dissolver was identical in dimension. with the Model 1 dissolver. The same dissolver product concentration was produced with unirradiated fuel using the same mercury level of $0.0005 \mathrm{M}$ mercury and 6.3M nitric acid feed at a flowrate of $45 \mathrm{ml} / \mathrm{min}$. However, the irradiated fuel required $0.006 \mathrm{M}$ mercury which is an order of magnitude higher. This is the first time a comparison has been made directly of highly irradiated fuel and the same unirradiated fuel using a continuous dissolver. The mercury level required in the small dissolver for irradiated fuel is the same as is used in the ICPP flowsheets for the processing of irradiated test reactor fuel.

\subsection{Description of Solids from Irradiated Fuel}

Undissolved uranium was elutriated from irradiated fuel in the small dissolver. Data for the eight plates were converted to the basis of one ETR element for comparison with other fuels. Forty grams per element of total solids containing 8.3 grams of undissolved uranium were collected by settling from the continuous dissolution. X-ray diffraction analyses did not show the presence of any crystalline uranium aluminide species. In order to show that the solids contained uranium aluminide fuel particles and was not entirely undissolved pieces of metal alloy, a comparison of uranium content of the components of the fuel element is made in Table IV. In all of the dissolutions, the quantity of aluminum per plate used was the same, and the flowrate and aluminum concentration in the dissolver product were constant so that the amount of uranium dissolved in a given time and the concentration of uranium in the solution varied with the content of uranium 
in the plate. The uranium content in the fuel plate is regulated by varying the concentration of uranium in the uranium-aluminum core. Those studied varied from $25 \mathrm{wt} \%$ to $32 \mathrm{wt} \%$ in these fuels; this is the maximum proportion of uranium that can result from elutriation of undissolved pieces of metal. On the other hand, the uranium concentration in the fuel particle itself depends upon whether the species is UAl 4 with 69 wt $\%$ uranium or $\mathrm{UAl}_{3}$ with $74 \mathrm{wt} \%$ uranium. The solids elutriated from unirradiated fuel were almost entirely uranium aluminide particles, and the ratio of uranium to uranium plus aluminum in the solids is nearly the same as the ratio in the corresponding uranium aluminide species. The irradiated fuel particles are calculated to contain 61 wt in uranium plus aluminum after a $38 \%$ burn-up of the uranium. By comparing the proportion of uranium to uranium plus aluminum in the solids (38 wt $\%$ ) to that in the core alloy and in the uranium aluminide, it is evident that the solids contain quantities of the uranium aluminide fuel particles because the uranium content of the solids is considerably above the 25 wt\% uranium that would be present in metal core pieces only. The dissolution of the elutriated solids during collection by the settling method, discussed in Appendix $B$, has given information on the relative solubility of the elutriated solids. We conclude that the uranium aluminide fuel particle retains its integrity during irradiation, but the decrease in uranium atoms and the increased proportion of aluminum atoms causes an increase in the solubility of the uranium aluminide fuel particle in the dissolver product solution.

TABLE IV.

COMPARISON OF URANIUM CONTENT OF FUELS AND ELUTRIATED SOLIDS

\begin{tabular}{|c|c|c|c|c|}
\hline & $\begin{array}{c}\text { Unirradiated } \\
\text { ETR-Syl } \\
\end{array}$ & $\begin{array}{c}\text { Unirradiated } \\
\text { ETR-B\&W } \\
\end{array}$ & $\begin{array}{c}\text { Unirradiated } \\
\text { ETR-AI } \\
\end{array}$ & $\begin{array}{c}\text { Irradiated } \\
\text { ETR-AI } \\
\end{array}$ \\
\hline Total Aluminum/Plate & $226 \mathrm{~g}$ & $226 \mathrm{~g}$ & $226 \mathrm{~g}$ & $226 \mathrm{~g}$ \\
\hline Total Uranium/Plate & $22.6 \mathrm{~g}$ & 22.68 & $28.4 \mathrm{~g}$ & $21.2 g$ \\
\hline Uranium/Fuel Plate Core & $25-27 \%$ & $25-27 \%$ & $30-32 \%$ & $25 \%(a)$ \\
\hline Uranium/Uranium Aluminide & $69 \%$ & $69 \%$ & $74 \%$ & $61_{10}^{\%}(\mathrm{a})$ \\
\hline $\begin{array}{l}\text { Uranium/Uranium }+ \\
\quad \text { Aluminum in Solids }\end{array}$ & $70 \%$ & $66 \%$ & $74 \%$ & $38 \%$ \\
\hline Uranium Content of Solids & $58 \%$ & $43 \%$ & $69 \%$ & $21 \%$ \\
\hline
\end{tabular}

(a) Values were calculated assuming 38\% burn-up of the original uranium.

The uranium contents of the elutriated solids vary depending on the quantity of other materials collected. As indicated by the lower uranium content ( $21 \mathrm{wt} \%$ ) in the total solids, shown in Table IV, the irradiated fuel contained larger amounts of extraneous materials than the other fuels studied. According to X-ray diffraction analyses, this 
was largely bayerite and boehmite which are hydrated aluminum oxides deposited on the element in the reactor; as a result, the presence of uranium aluminide in the solids is even more positive because the presence of aluminum oxide makes the ratio of uranium to uranium plus aluminum lower than if only the metal and fuel particles were present. Some fission products, which were collected and were insoluble in concentrated nitric acid, are discussed in Appendix $B$.

\section{DISSOLUTION OF URANIUM ALUMINIDE POWDER}

Commercial uranium aluminide powder used to fabricate test reactor elements by powder metallurgy (COM-UAl ${ }_{\mathrm{X}}$ ) was used for most of the dissolution studies because the elutriated solids contained materials other than uranium aluminide such as silicon, boron, and aluminum oxides. As described in Section 1.4 and Appendix C, the rate of dissolution increases with increasing temperature. Details of the dissolution studies and complete data are given in Appendix $\mathrm{C}$.

\subsection{Effect of Particle Size}

At all temperatures, the rate for COM-UAl was the same as for solids elutriated from ETR-AI fuel even though ${ }^{x}$ the particle size of the COM-UAl powder was considerably larger as seen in the photos in Section 1.3 and ${ }^{x}$ the sieve distribution shown in Table C-I in the Appendix. In order to determine the effect of particle size, a series of dissolutions was made using two different size fractions of the same commercial UAl powder. The fractions studied were < 325 but $>400$ mesh which includes 37 to $44 \mu$ particles and < 100 but > 140 mesh which includes 105 to $150 \mu$ particles. These fractions represent the larger particles from the two core types; the larger wrought alloy particles are estimated to be 25-50 , while the powder metallurgical fuel particles must be $<150 \mu$ but not more than $25 \mathrm{wt} \%$ can be $<44 \mu$. Data in Figure 8 show that the particle size effect is evident at $30^{\circ}$ and $60^{\circ} \mathrm{C}$, but the difference is not detected at $103^{\circ} \mathrm{C}$. This indicates that particle size effect in this range of sizes is not sufficient to cause the entire difference in dissolution rate for various solids observed in other studies.

\subsection{Dissolution in Process Solutions and Reagents}

Both nitric acid and mercuric nitrate concentrations vary in the dissolver during dissolution of aluminum. The effect of these upon the dissolution rate of uranium aluminide was determined. The addition of mercury catalyst at $0.007 \mathrm{M}$, the usual flowsheet concentration, slightly increases the rate of dissolution, but mercury is not required to dissolve $\mathrm{UAl}_{3}$ or $\mathrm{UAl}_{4}$ in nitric acid. The rate of dissolution increases with increasing acid up to $15.6 \mathrm{M}$, and the rate is extremely slow in aciddeficient aluminum nitrate. In both regards, the dissolution of the uranium aluminide resembles the dissolution of uranium metal rather than the dissolution of aluminum metal.

A new processing scheme, called coprocessing, is being initiated at ICPP in which waste volumes are decreased by using dissolver product from aluminum fuel processing instead of commercial aluminum nitrate to 
complex the dissolver product from zirconium fuel processing. Data for the dissolution rate of uranium aluminide in the combined dissolver products given in Figure 9 show that the dissolution is far more rapid after adding the zirconium solution containing $6.5 \mathrm{M}$ fluoride. Even at $30 \mathrm{C}$, where coprocess solutions are held to minimize corrosion, the rate is very adequate for processing schedules. The oxidant, chromic oxide, is normally added to the aluminum nitrate solution prior to combining with the zirconium dissolver product. Figure 9 shows that this will retard further dissolution of the fuel particles in the aluminum solution while it will not affect the dissolution after combining with the zirconium fluoride solution.

Other dissolvents examined included $3 M$ sodium hydroxide. The uranium aluminide did not dissolve in this reagent. Addition of hydrogen peroxide was very effective at the beginning of the dissolution, but the dissolution did not proceed to completion even with the addition of more peroxide (see Appendix C). Other oxidants were less effective and acted in a similar fashion. A number of chemical additives for the dissolver product solution were examined, but none increased the dissolution rate sufficiently to consider them for process use in the dissolver (see Appendix C).

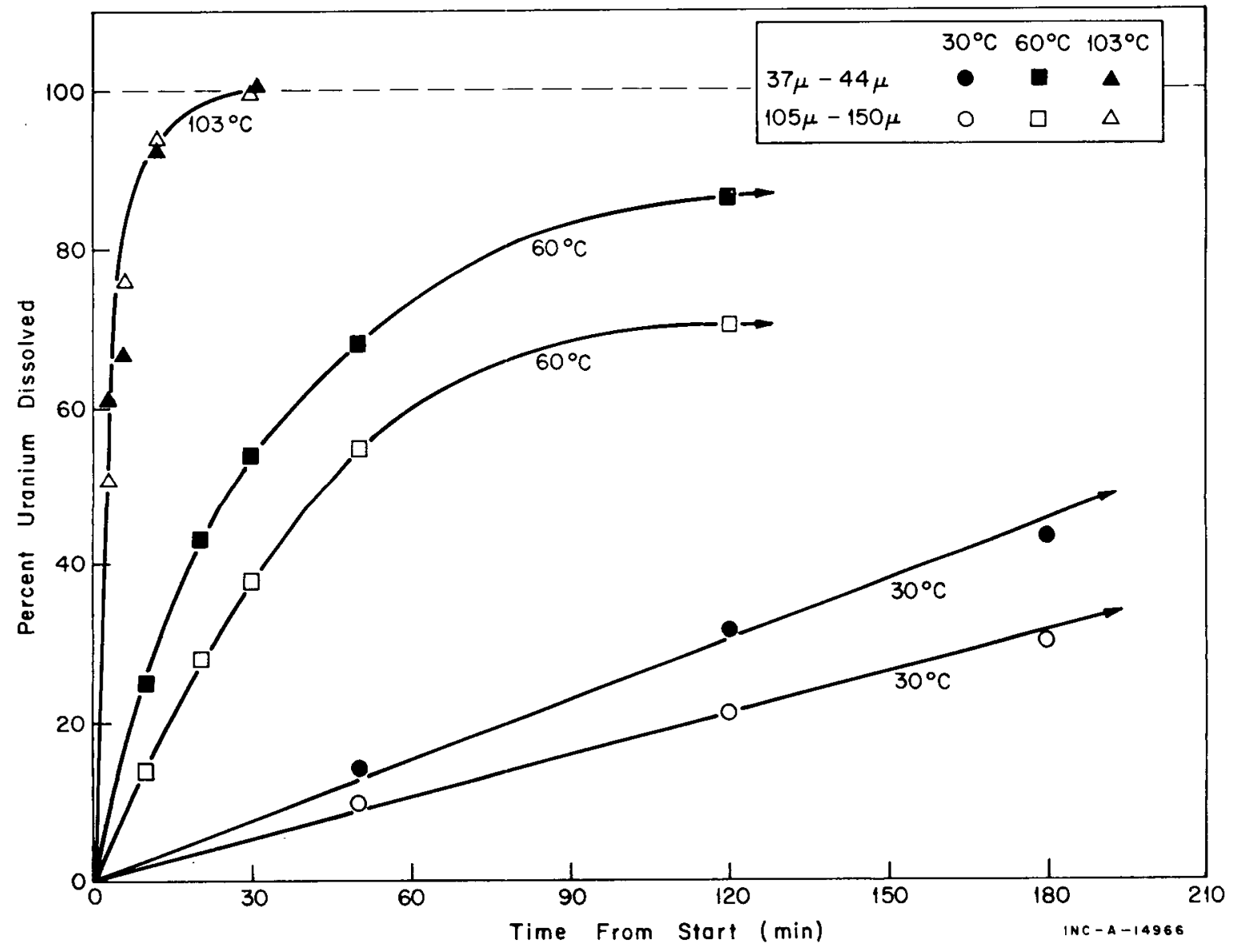

Figure 8. Effect of particle size on dissolution of uranium aluminide. 


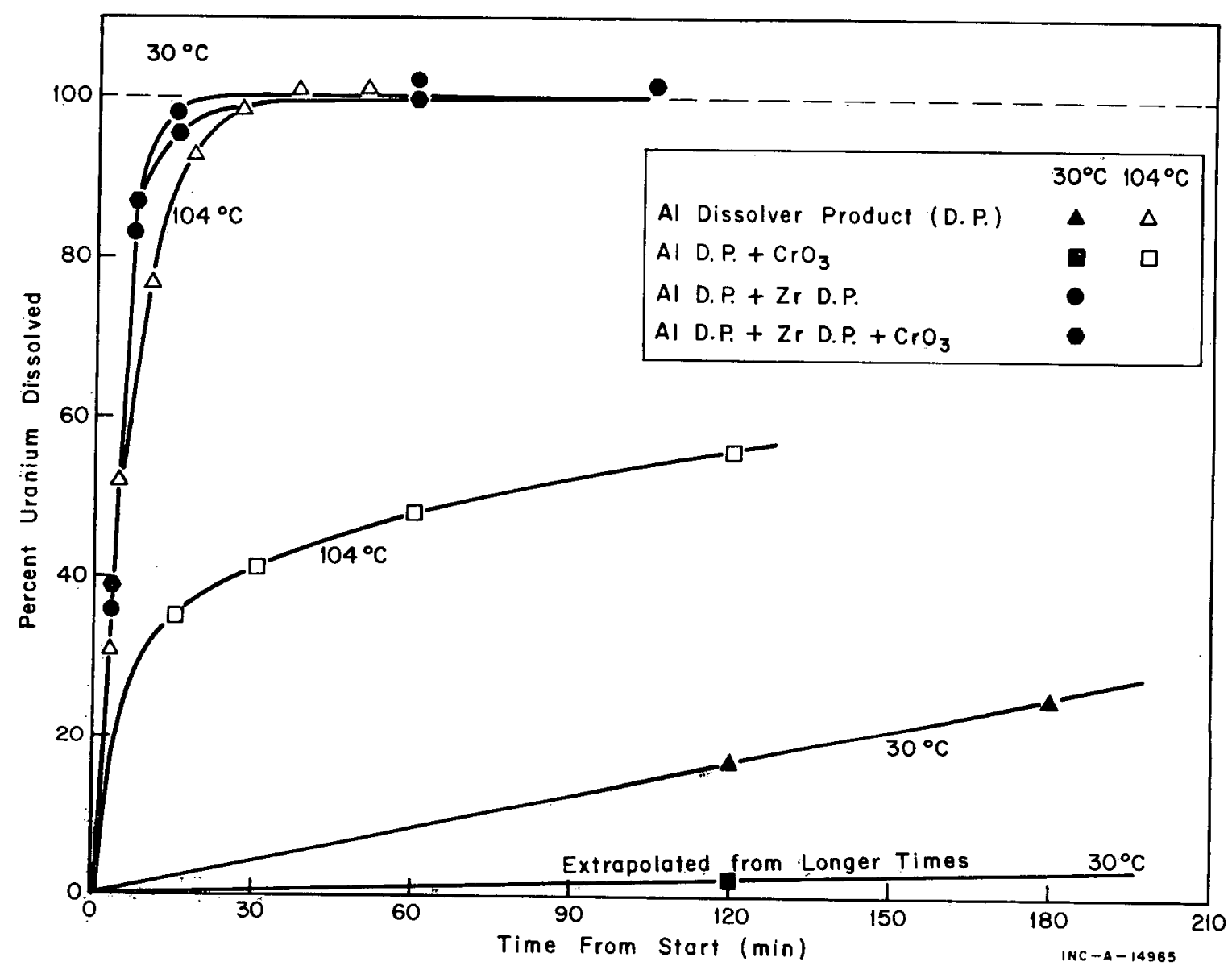

Figure 9. Effect of coprocessing on dissolution of uranium aluminide (COM-UAI ${ }_{x}$ ). (AI D.P. contains $1.5 \mathrm{M} \mathrm{Al}\left(\mathrm{NO}_{3}\right)_{3}-1.5 \mathrm{M} \mathrm{HNO}_{3}-$

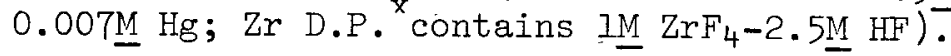




\section{COHCLUSIOINS}

The difference in dissolution rate of uranium aluminides and aluminum matrix in the fuel core is sufficient to permit elutriation of fuel particles from a continuous dissolver. The UAl 4 was elutriated from wrought alloy fuels such as have been processed for a number of years, while the $\mathrm{UAl}_{3}$ was elutriated from powder metallurgical fuel produced according to current fabrication specifications. In the small laboratory dissolver, the amount of undissolved uranium elutriated was the same for both types of fuel; however, the particles elutriated from the powder metallurgical fuel dissolves somewhat more slowly than those from the wrought alloy fuel and require more time to dissolve completely. The total quantity of undissolved uranium elutriated increases with increasing content of uranium in the fuel.

The first of the powder metallurgical fuel, which was processed during the last campaign, appears to be different from powder metallurgical fuels being currently fabricated. The fuel core contained $\mathrm{UAl}_{4}$ rather than $\mathrm{UAl}_{3}$ and larger amounts of other inert materials. The elutriated solids compacted into a very hard cake unlike the solids from other fuels studied. The uranium fuel particles elutriated from this fuel have the same dissolution rate as those from wrought alloy fuels. It has been concluded that plugging in the transfer lines during the last campaign may have been due to larger amounts of insoluble materials and to the unusual nature of this particular fuel; however, the quantity of insoluble solids, particularly $\alpha$-alumina, in all powder metallurgical fiuels exceeds that found in the older wrought alloy fuel.

In laboratory studies, uranium aluminide particles were elutriated and collected from dissolved, fully irradiated ETR fuel fabricated by the powder metallurgical method, but they no longer have a crystalline $\mathrm{X}$-ray diffraction pattern. Apparently, the increase in proportion of aluminum atoms in the particle caused by the burn-up of uranium atoms results in an increase in dissolution rate of the fuel particles, but the increased rate is not sufficient to prevent preferential dissolution of the aluminum matrix.

The most effective way to increase the rate of dissolution of uranium aluminide in aluminum dissolver product is by increasing the temperature of the dissolver product solution. At room temperature, the particles required several hours to dissolve, while 10 to 30 minutes is sufficient to dissolve all of the uranium at the boiling point; the fuel particles elutriated from powder metallurgical fuel require the longer time to dissolve. The dissolution rate of uranium aluminide increases with increasing nitric acid concentration. The rate of dissolution is extremely slow in acid deficient aluminum nitrate solutions. Uranium aluminide is insoluble in 3M sodium hydroxide. Increased mercury concentration only slightly increases the dissolution rate, especially at the boiling point, and mercury is not required for the dissolution. In respect to chemical reactivity in nitrate media, the uranium aluminide resembles uranium metal rather than aluminum metal. No chemical additives or catalysts were found to increase the dissolution rate in 
aluminum dissolver product solutions.

Addition of zirconium fluoride dissolver product solutions having IM zirconium fluoride, and $2.5 \mathrm{M}$ hydrogen fluoride, greatly increases the rate of dissolution of uranium aluminide particles, and complete dissolution is obtained in 15 to 20 minutes at $30^{\circ} \mathrm{C}$. The addition of chromic oxide, the zirconium process oxidant for uranium, to the aluminum dissolver product prior to combining it with the fluoride sclution greatly retards the dissolution of the uranium aluminide, but it does not affect the dissolution rate in the combined aluminum nitrate and zirconium fluoride solutions. 


\section{RECOMMENDATIONS FOR OPERATION OF ICPP}

The data obtained from these studies cannot be used directly to estimate the quantity of uranium aluminide fuel particles elutriated from the plant dissolver because the ICPP dissolver is 13 times taller than the small dissolver used for these studies, and the residence time is correspondingly longer at the same flowrate and velocity. The relatively large quantities elutriated from the small dissolver, however, indicate that elutriation of uranium aluminide is possible in ICPP because the time required to dissolve elutriated particles is greater than the probable residence time in the plant dissolver. By observing the recommendations given below, the dissolution of elutriated particles can be assured, thus eliminating the potential hazards of undissolved uranium accumulating in the head-end of the process or being removed. from the dissolver product with undesirable solids in the ICPP centrifuge.

1. Operate the continuous dissolvers with maximum residence time.

2. Maintain as high a solution temperature as possible after the dissolver product leaves the dissolver to assure complete dissolution of elutriated solids in a minimum time.

3. Coprocess aluminum fuels, whenever possible, particularly powder metallurgical fuel with high uranium content. Do not add chromic acid to the aluminum dissolver product prior to combination with the zirconium dissolver product unless complete dissolution of the uranium has been assured.

4. Agitate solution in all dissolver product collection vessels to prevent settling of solids prior to complete dissolution of the uranium. 


\section{REFERENCES}

1. B. E. Paige, G. W. Gibson, and K. L. Rohde, The Effect of Silicon on Fabrication and Reprocessing of Aluminum Alloy Reactor Fuels, IN-1194 (November 1968).

2. G. W. Gibson, The Development of Powdered Uranium-Aluminide Compounds for Use as Nuclear Reactor Fuels, IN-I133 (December 1967).

3. G. W. Gibson, M. J. Graber, and W. C. Francis, Annual Progress Report on Fuel Element Development for FY-1963, IDO-16934 (November 1963).

4. D. M. Paige et al, Pilot Plant Studies of Continuous Nitric Acid Dissolution of Uranium-Aluminum Alloy, IDO-14304 (May 1954).

5. A. F. Boeglin et al, The Nitric Acid Dissolution of Uranium-Aluminum Alloy in a Flooded Continuous Dissover, IDO-14321 (December 1954).

6. A. F. Boeglin et al, Continuous Dissolution of Uranium-Aluminum Reactor Fuels, IDO-14341 (June 1955).

7. R. D. Fletcher, M. E. Jacobson, and H. R. Beard, Effect of Alloying Constituents on Aluminum Dissolution Rates, IDO-14606 (April 1963). 
APPENDIX A

CONTINUOUS DISSOLVER OPERATION 


\section{APPENDIX A}

\section{CONTINUOUS DISSOLVER OPERATION}

A number of dissolvers for the continuous dissolution of aluminum fuel have been designed and operated at this laboratory $(4,5,6)$. These dissolvers have had diameters from two to five inches and were eight to twenty-five feet tall. The uniquely small dissolver used for the current studies has the advantage of requiring far less fuel to charge and having fewer space limitations. Some of the similarities and some of the differences from other continuous dissolvers are discussed here.

\section{OPERATION OF MODEL I DISSOLVER}

A diagram of the 3/4-inch Model 1 continuous dissolver is shown in Figure A-l. Nitric acid at 85 to $95^{\circ} \mathrm{C}$ was pumped into the bottom of the dissolver. In some cases, a heat lamp was required to initiate the dissolution, but after initiation, the reaction was self-sustaining. Thermocouples showed that the lower portion of the dissolver was at the boiling point $\left(103^{\circ} \mathrm{C}\right)$ during dissolutions while the upper portion of the dissolver was about $1^{\circ} \mathrm{C}$ lower. The effluent was not discharged at a steady rate because of the surging which occurred in the dissolver; flowrates were determined from the volume of effluent collected over a period of three to four minutes.

According to earlier work. $(6)$, the increase in dissolution rate, corresponding to an increase in aluminum concentration in the dissolver product, is negligible above the 8-foot level in an 18-foot dissolver, whereas the increase is very significant at 2,4 , and 6 feet; as a result, the height of the submerged fuel in the dissolver can vary considerably in the upper portion of the 18-foot dissolver without drastically affecting the dissolver product concentration. In spite of the large fuel surface area of the fuel pieces in the 19-inch dissolver, the fuel height is extremely important, and it is necessary to keep the fuel height constant. Steady state could not be maintained by charging at a semi-constant rate; however, the fuel height was effectively constant if kept above the product discharge line because dissolution above this point by the condensed acid was minimized by the absence of mercury catalyst.

The effect of acid feed rate was determined for 1100 aluminum using 6.3M nitric acid, (the ICPP acid feed) and several mercury catalyst levels. Data in Figure A-2 show that the rate of the aluminum dissolution did increase linearly with increased acid feed rate, but the slopes were not the same for different mercury catalyst levels; therefore, the flowrates could not be normalized for other correlations as has been the case 


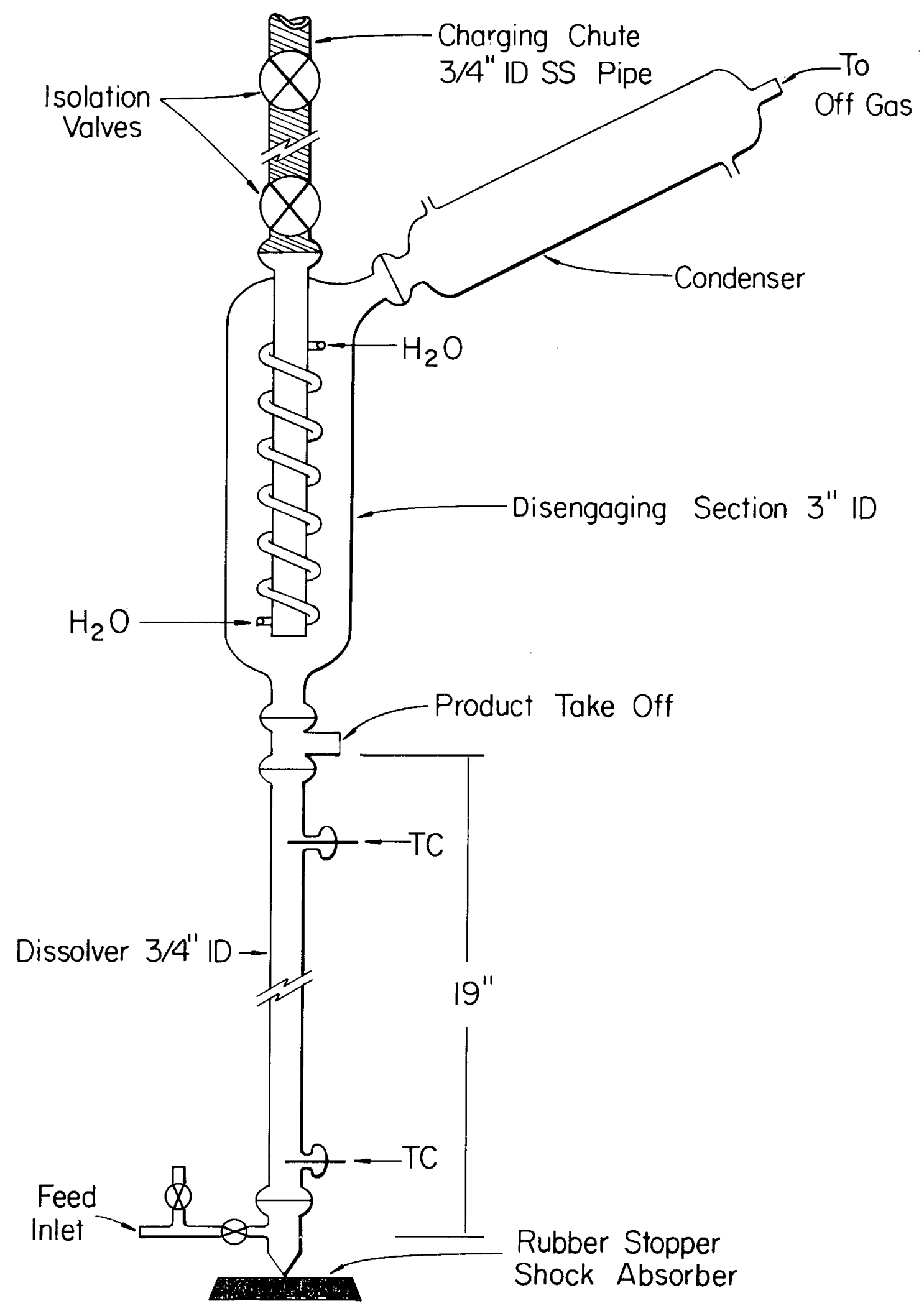

Figure A-l. Diagram of continuous dissolver, Model 1. 


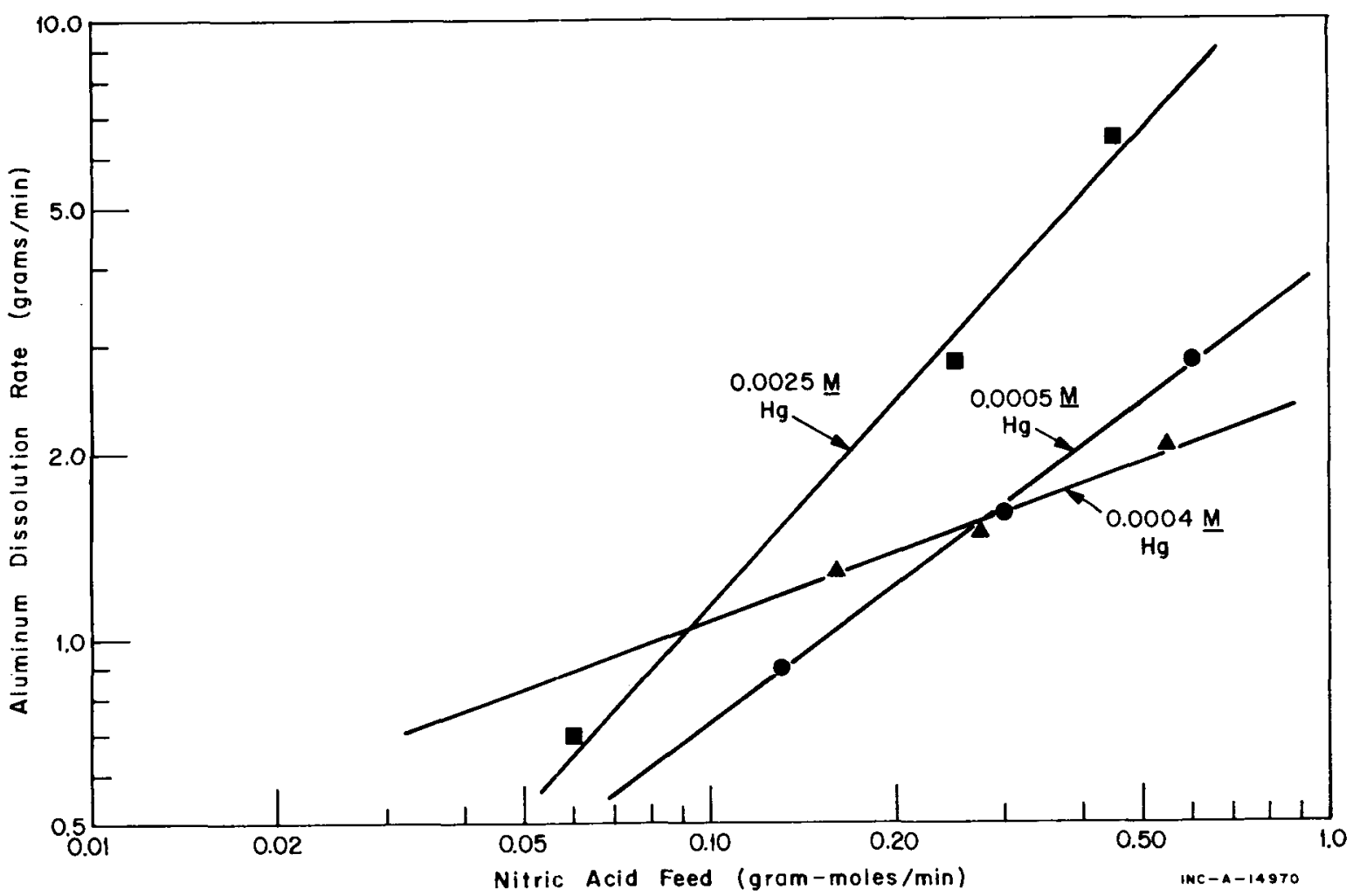

Figure A-2. Effect of acid feed rate on aluminum dissolution.

for previous continuous dissolver studies. This is probably due to the short height of the dissolver. Thereafter, a single flowrate of $45 \mathrm{ml} / \mathrm{min}$, which was comparable to the plant rate (see Table I in the text), was used for all experiments. At this constant flowrate, the effect of mercury catalyst concentration was linear, and as seen in Figure A-3, the optimim level required for 1100 aluminum was 0.0004 to $0.0005 \mathrm{M}$. The same level was satisfactory for all unirradiated ETR fuels. Limited dissolutions made with ATR-AI fuel indicated that a higher level of mercury would be required as would be expected because of the 606I-T6 aluminum cladding.

Some observations of the dissolution process were made in the glass dissolver. Partially dissolved pieces, with and without clad, were seen throughout the dissolution and were similar to those in fuel remaining in the dissolver after the dissolution shown in Figure A-4. Mostly aluminum cladding was exposed in the original fuel, and 15 to 20 minutes were required to reach steady state with regard to uranium concentration while less than five minutes were required to reach steady state with regard to the aluminum. Surging of the liquid up through the dissolver was evident throughout the dissolutions and was especially evident at low flowrates. The vigorous evolution of gas from the reaction caused an upward motion of the solution and fuel pieces sometimes wedged in the dissolver. This jamming caused a temporary decrease in product concentration; the problem was most pronounced when the pieces were less than 3/8-inch wide. The upward motion of the solution together with gas 


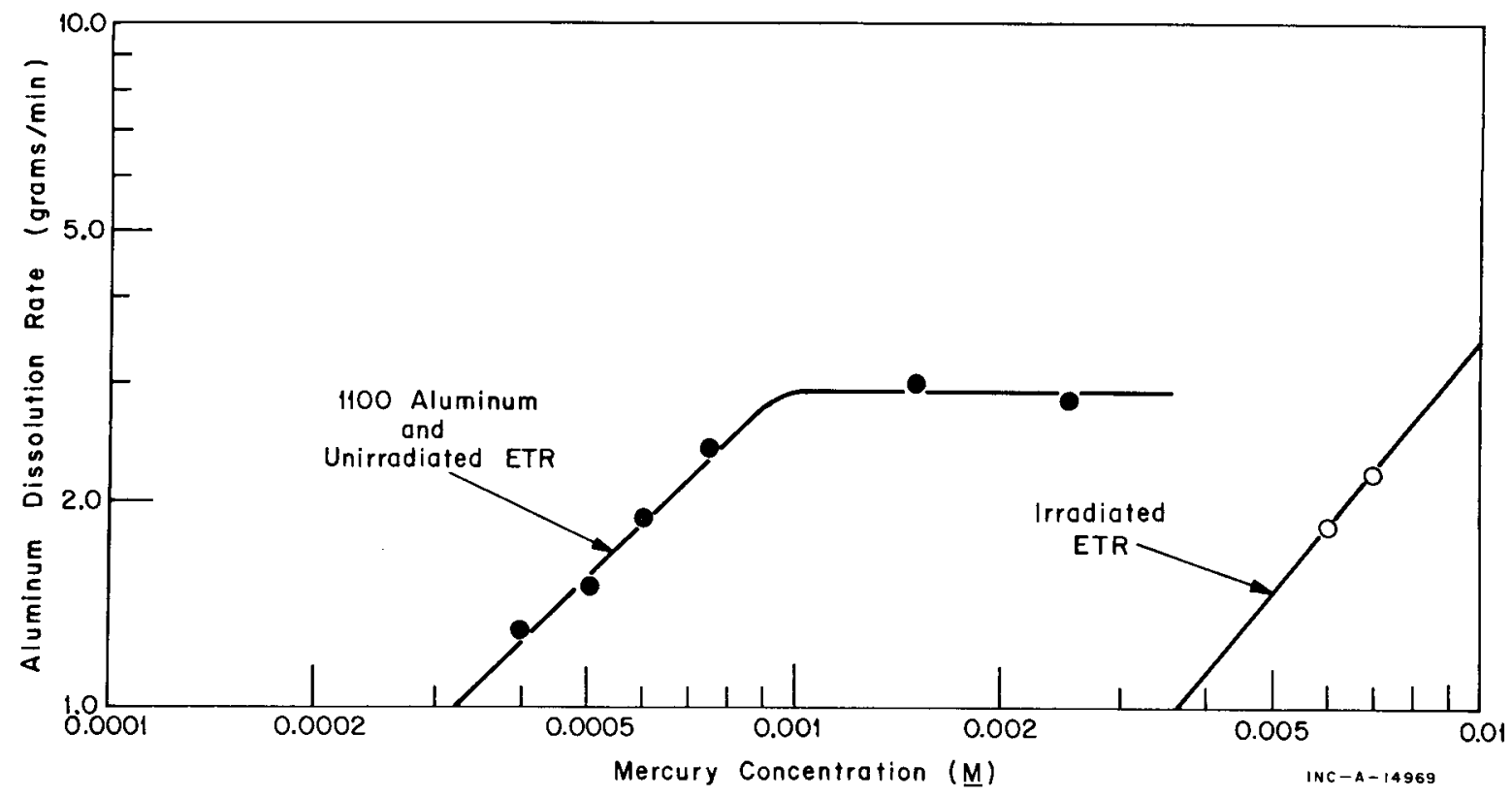

Figure A-3. Effect of mercury concentration on aluminum dissolution.

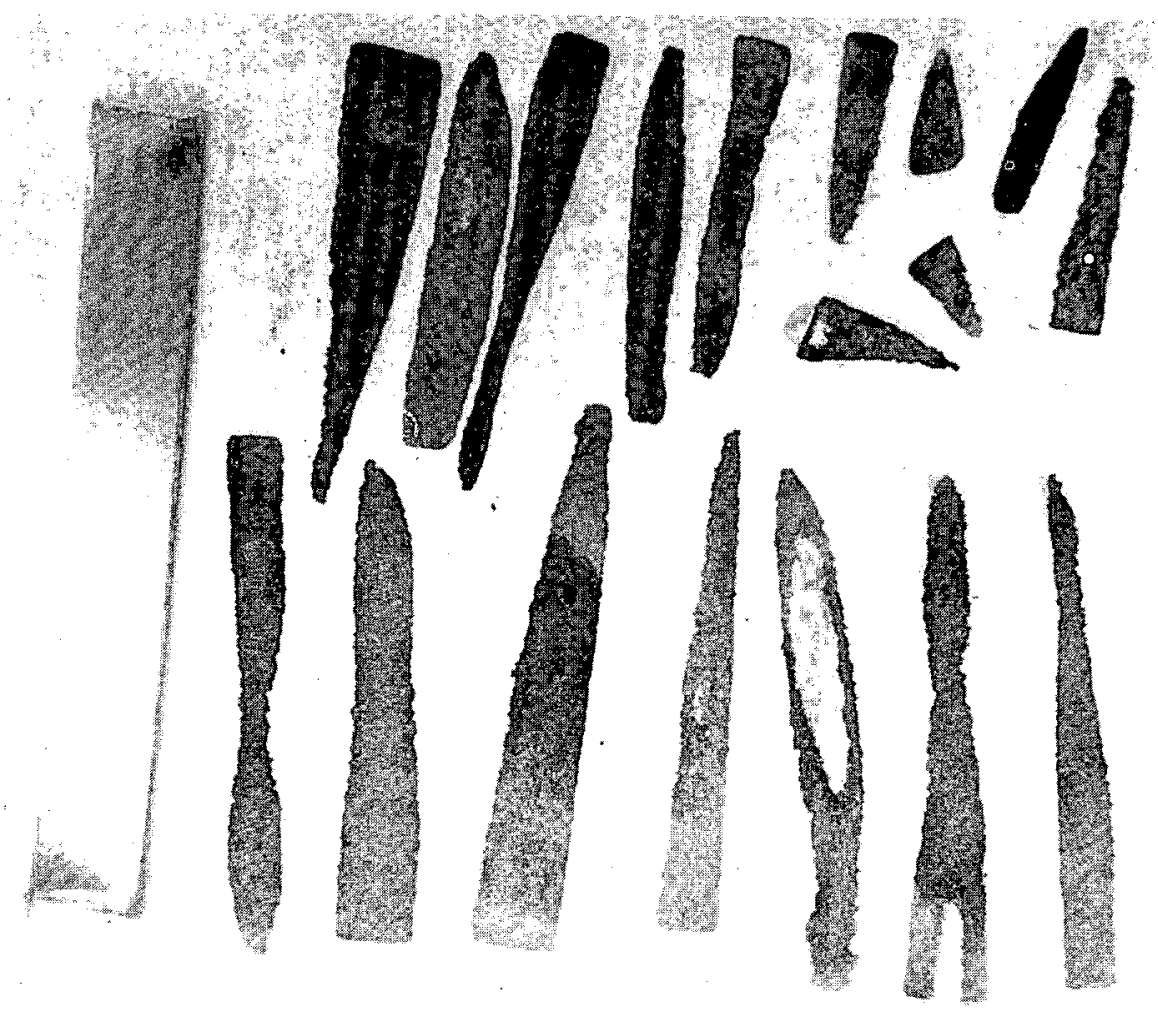

Figure A-4. Residual ETR fuel from continuous dissolver. 
evolution at the surface of the metal was responsible for elutriation of small fuel pieces described in Appendix B.

\section{COMPARISON OF MODEL 1 AND MODEL 2 DISSOLVERS}

The Model 2 dissolver used for Hot Cell experiments and shown in the text (Figure 2) had identical height and diameter as the Model 1 dissolver. Figure A-5 is a diagram of the Hot Cell equipment. The product cooler and settling vessel are described in Appendix B. The Model 2 dissolver was operated the same as the Model 1 dissolver at $45 \mathrm{ml} / \mathrm{min}$ flowrate with fuel height above the product outlet. The mercury level required $(0.0005 \underline{M})$ was the same for unirradiated ETR-B\&W and ETR-AI fuel. The irradiated fuel, however, required an order of magnitude higher mercury level of $0.006 \mathrm{M}$ to obtain the same dissolver product concentration as is shown in Figure A-3. 


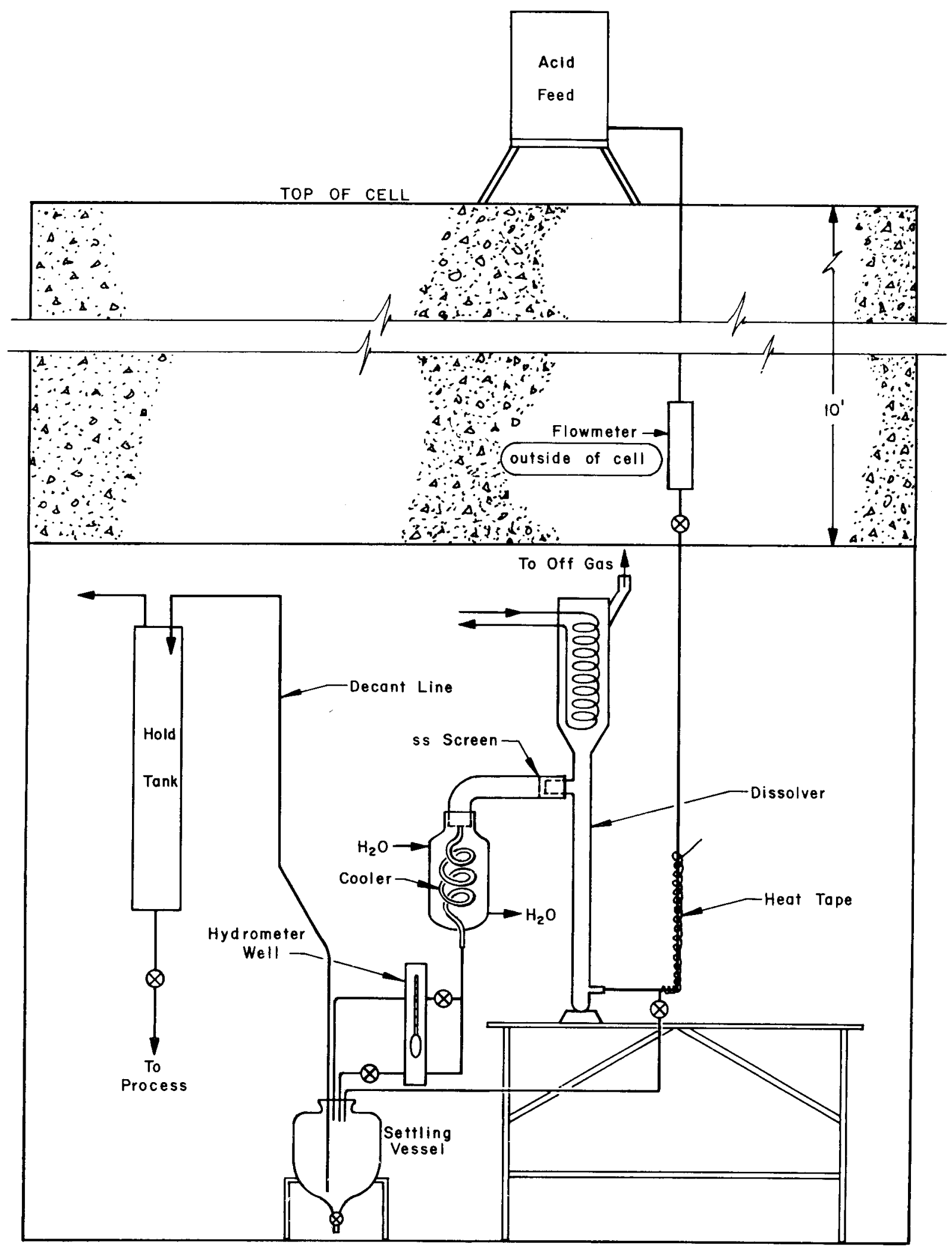

Figure A-5. Diagram of hot cell equipment. 
APPENDIX B

COMPARISON OF COLLECTION SYSTEMS AND SOLIDS 


\section{APPENDIX B \\ COMPARISON OF COLLECTION SYSTEMS AND SOLIDS}

1. COMPARISON OF SOLIDS

\subsection{Centrifugation of Solids}

The laboratory centrifuge [a] used to collect solids elutriated from Model 1 dissolver is shown in Figure B-1. Figure B-2 is a diagram of the interior of the centrifuge showing the skimmer which was designed to remove the liquid from the centrifuge at the end of each run. The skimmer, fabricated from 1/2-inch stainless steel tubing, was connected to a vacuum line. By rotating the skimmer clockwise into the top outer edge of the bowl, all the liquid was transferred into a receiving vessel. The uranium concentration in the supernate skimmed from the centrifuge was twice that of the centrifuged effluent after four to five hours of operation and continued to increase with longer operation times. This showed that dissolution was continuing in the hot dissolver product in the centrifuge bowl. It also showed that the exchange of feed liquid with the liquid in the centrifuge bowl was rot complete during continuous operation indicating a shorter residence time in the centrifuge than calculated on the basis of flow and hold-up volume.

The basket shown in the effluent line in Figure B-I was installed to collect large pieces of undissolved metal which elutriated from the dissolver. These pieces continued to dissolve in the basket necessitating off-gas collection at this point. Figure B-3 shows pieces of elutriated fuel together with a piece of the original fuel for comparison. Small pieces of metal which passed through the screen were collected with the other solids in the centrifuge and contributed to the overall amount of undissolved uranium. The metal content was about six to seven wt\% in the solids collected from ETR-B\&W and ETR-AI.

\subsection{Settling of the Solids}

The settling vessel and rack used to collect the solids in the hot cell are shown in Figure B-4. This equipment was designed to simplify the solids collection procedure for remote operation with the Model 2 dissolver. The dissolver product was chilled to $22^{\circ} \mathrm{C}$ in a cooling coil immediately after leaving the dissolver to reduce the dissol-ution rate

[a]

International Centrifuge Company (No. 1399) developing a force of $1150 \mathrm{x} \mathrm{G}$ at $4000 \mathrm{rpm}$; solid-type stainless steel basket (No. 134I), five-inch diameter and 2 1/2 inches deep; stainless steel draining chamber (No. 1320) permitting operation in a continuous mode. 


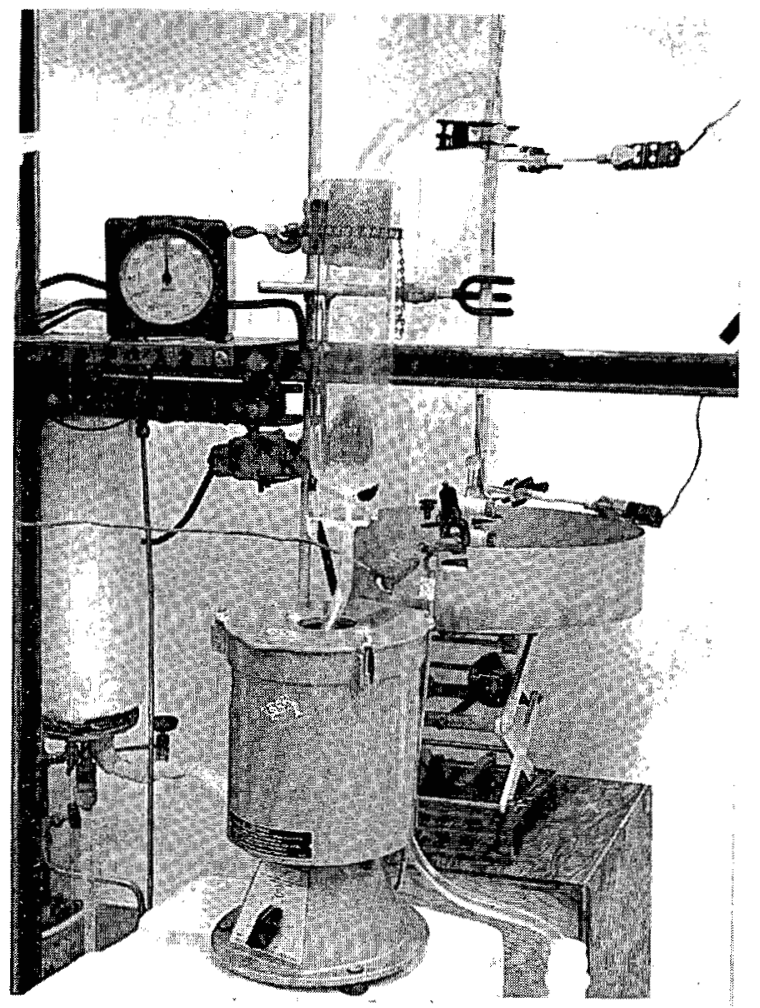

Figure B-l. Continuous centrifuge used to collect elutriated solids.

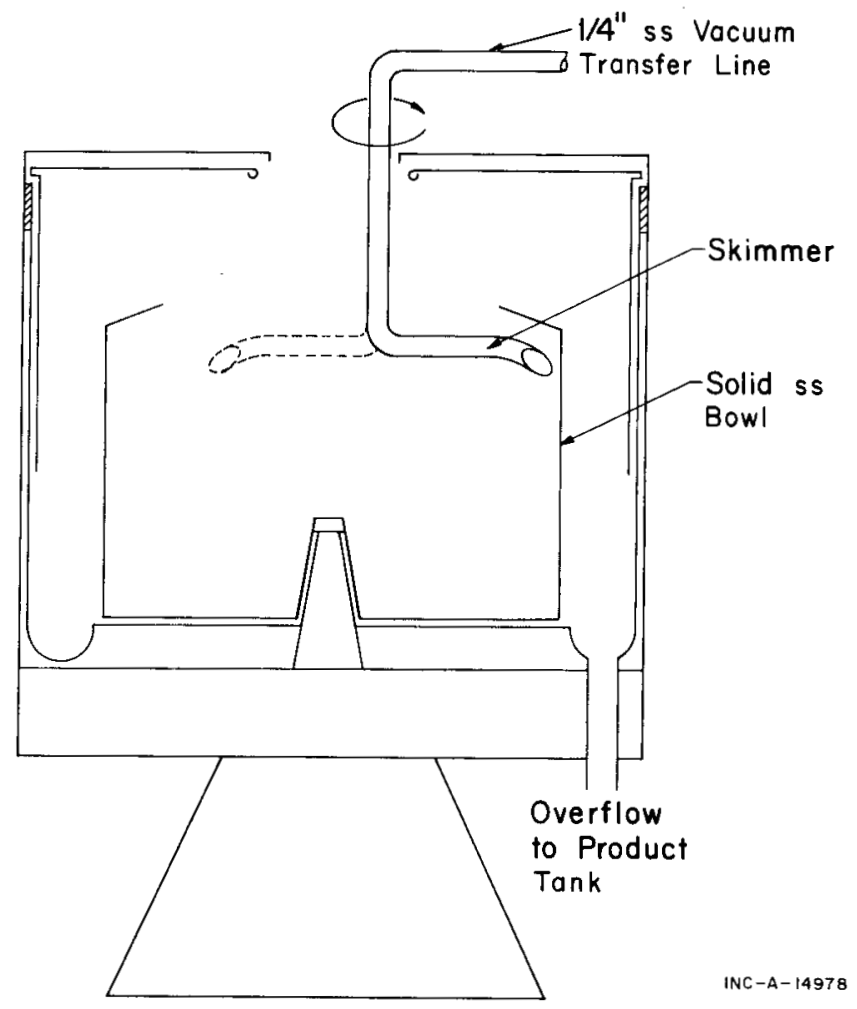

Figure B-2. Diagram of centrifuge and skimmer. 


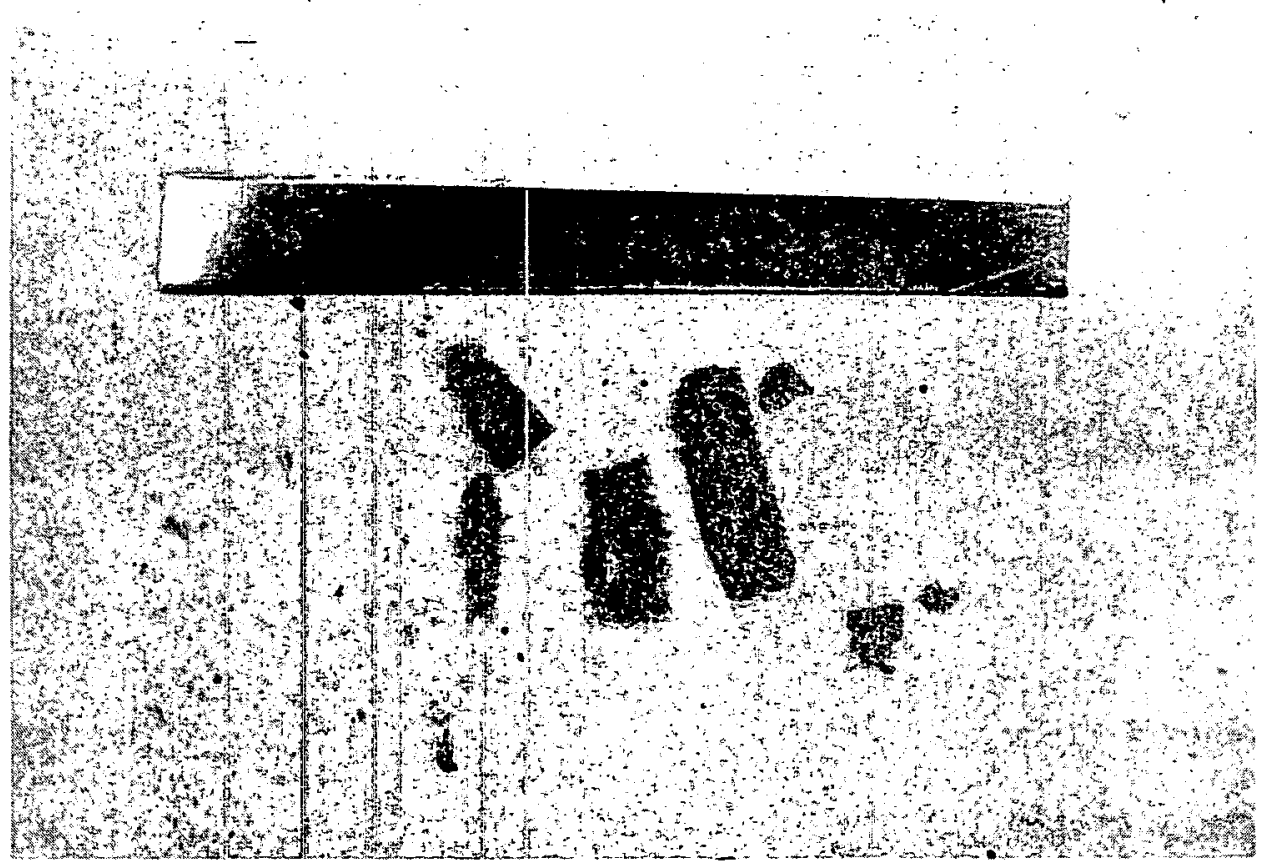

Figure B-3. Fuel pieces elutriated from the continuous dissolver.

of uranium-aluminide, and an additional cooling coil in the settling vessel maintained the temperature at $19^{\circ} \mathrm{C}$. The solution was collected in this vessel throughout the dissolution and allowed to stand overnight to complete the settling; the supernate was then decanted from the vessel, and fresh dissolver product was collected in the vessel. The procedure was repeated accumulating solids until the desired amount of fuei was dissolved. Finally, the collected solids were washed with 15 liters of water, allowed to settle overnight, transferred, dried, and weighed. This procedure permitted all uranium-aluminide particles (density $=6.3 \mathrm{~g} / \mathrm{cm}^{3}$ ) with a diameter of greater than $2 \mu$ to settle from the solution.

\subsection{Comparison of Centrifugation and Settling}

Both unirradiated ETR-B\&W and ETR-AI fuel were dissolved and solids collected in the hot cell equipment

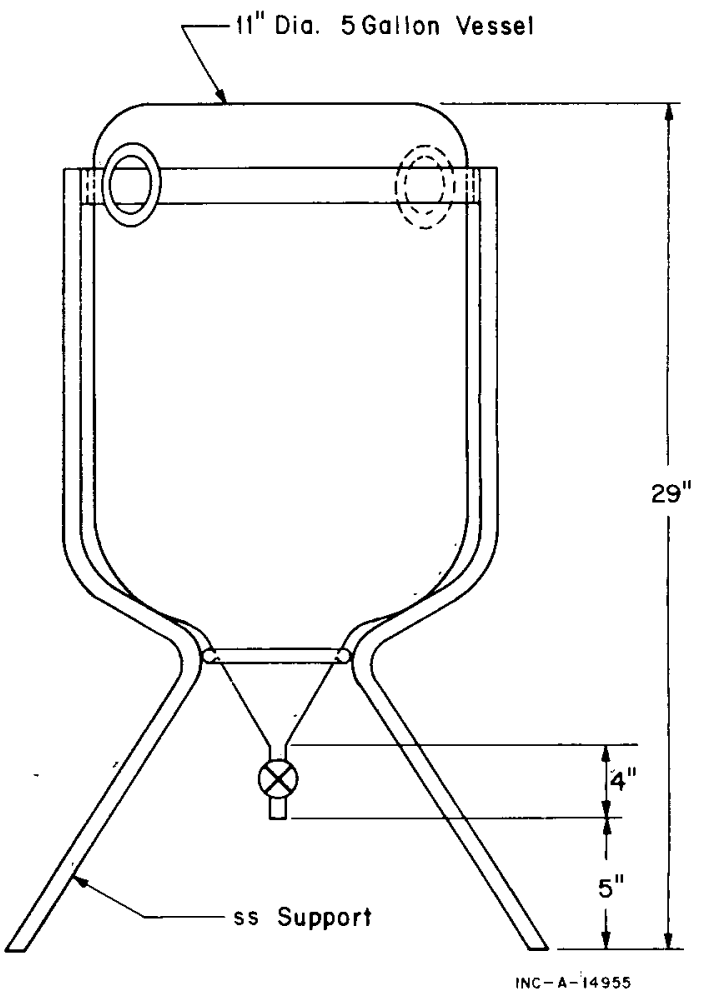

Figure B-4. Settling vessel used to collect elutriated solids. 
for comparison with previous studies using the Model 1 dissolver and the continuous centrifuge for collection of solids. Since the Model 2 dissolver functioned identically with the Model 1 dissolver (see Appendix A), it is assumed that the solids elutriated from the dissolvers were identical. Table B-I presents a comparison of the two method of collection. Only about $10 \%$ as many total solids were collected from ETR-B\&W solids by the settling method as by centrifugation, whereas about half as many insoluble solids were collected; therefore, the loss of solids by settling was almost entirely due to a decrease of uranium bearing solids, and only $0.6 \mathrm{wt} \%$ of the charged uranium was collected as undissolved uranium. By contrast, the dissolution with ETR-AI fuel produced $60 \%$ as many solids by settling as were collected by centrifugation, and $14 \%$ of the charged uranium was undissolved. The difference is primarily due to the difference in the kind and size of the uranium particles produced by the two fuels.

TABLE B-I.

COMPARISON OF SOLIDS COLLECTED BY DIFFERENT SYSTEMS FROM UNIRRADIATED FUEL

\begin{tabular}{|c|c|c|c|c|}
\hline & $\begin{array}{c}\text { Solids from } \\
\text { Collected } \\
\text { in } \\
\text { Centrifuge }\end{array}$ & $\begin{array}{c}\text { ETR-B\&W } \\
\text { Collected } \\
\text { by } \\
\text { Settling }\end{array}$ & $\begin{array}{c}\text { Solids fr } \\
\text { Collected } \\
\text { in } \\
\text { Centrifuge }\end{array}$ & $\begin{array}{c}\frac{E T R-A I}{\text { Collected }} \\
\text { by } \\
\text { Settling }\end{array}$ \\
\hline Elutriated Solids/Element & $167 \mathrm{gm}$ & $17 \mathrm{gm}$ & $196 \mathrm{gm}$ & $120 \mathrm{gm}$ \\
\hline Insoluble Solids/Element & $13.3 \mathrm{gm}$ & $7 \mathrm{gm}$ & $5.7 \mathrm{gm}$ & $4.8 \mathrm{gm}$ \\
\hline Undissolved U/Element & $72 \mathrm{gm}$ & $2.6 \mathrm{gm}$ & $135 \mathrm{gm}$ & $75 \mathrm{gm}$ \\
\hline U Charged but not Dissolved & 17 wt \% & $0.6 \mathrm{wt} \%$ & 25 wt \% & $14 \mathrm{wt} \%$ \\
\hline
\end{tabular}

\section{SOLIDS FROM IRRADIATED FUEL}

The solids produced per irradiated ETR-AI fuel element and collected in the settling vessel weighed 40 grams and contained 8.3 grams of undissolved uranium or $2 \mathrm{wt} \%$ of the charged uranium. The values for these solids are between the values obtained for the two unirradiated fuels in the same equipment. Using different methods of collection it is not possible to ascertain the quantity of material elutriated from the dissolver; however, one would suspect that the particles elutriated are similar to those from the unirradiated fuel in quantity and that the difference between irradiated and unirradiated fuel seen here is due to varying dissolution rates of the uranium particles being collected by settling. The dissolution rate of the irradiated particle is between that of particles from unirradiated ETR-Syl and ETR-AI.

As shown in Section 2.3 of the text, the solids from the irradiated fuel contained uranium-aluminide fuel particles; however, the quantity of uranium in the particles has been decreased by the fission of uranium atoms. The uranium content of the uranium-aluminide fuel particles is $70 \mathrm{wt} \%$ in unirradiated ETR-AI fuel and is calculated to have decreased to $60 \mathrm{wt} \%$ after burn-up, while uranium in the unirradiated ETR-B\&W is 
believed to be about $50 \mathrm{wt} \%$. The hot cell data indicate that the dissolution rate is greatest for the fuel with the largest excess aluminum and lowest uranium content in the fuel particle.

The major fission products detected by emission spectroscopy in residues which were insoluble in concentrated nitric acid were zirconium with smaller quantities of molybdenum, ruthenium, paladium, and traces of silver and rhodium. Other materials identified were major quantities of phosphorous and minor amounts of silicon, and aluminum, which is probably present as insoluble a-alumina. Only a trace of boron was detected in the insoluble solids collected by settling. 
APPENDIX C

DISSOLUTION OF URANIUM ALUMINIDE 
APPENDIX C

\section{DISSOLUTION OF URANIUM ALUMINIDE}

The dissolution of uranium aluminide was studied by adding weighed amounts of the solid material to $500 \mathrm{ml}$ of solution so that the solidsto-liquid ratio was the same as existed in the dissolver product prior to separation of the solids. Measured aliquots were removed at selected time intervals, filtered to stop further dissolution, and analyzed for dissolved uranium. Most of the studies were made with uranium aluminide powder of the type used in making test reactor fuels by powder metallurgy (referred to as $\mathrm{COM}-U A_{\mathrm{X}}$ ). Solids from unirradiated fuel were also studied.

1. DISSOLUTION OF URANIUM ALUMINIDE ELUTRIATED FROM ETR FUEL

\subsection{Effect of Temperature}

The relative rates of dissolution of solids elutriated from ETR-Syl, the wrought alloy fuel, and from ETR-B\&W and ETR-AI, the powder metallurgy fuels, were determined in a typical dissolver product solution containing $1.5 \mathrm{M}$ aluminum nitrate, $1.5 \mathrm{M}$ nitric acid, and $0.007 \mathrm{M}$ mercuric nitrate. Comparison of these fuels with COM-UAl is made in section 1.4 of the text. Figures $\mathrm{C}-1,2,3$, and 4 are plots of the rate of aluminum dissolved against time at $30^{\circ}, 60^{\circ}, 80^{\circ}$, and $103^{\circ} \mathrm{C}$ and can be used to estimate the quantity of elutriated solids still remaining after any given time of solution contact.

\subsection{Effect of Particle Size}

Solids from ETR-Syl and ETR-AI were sieved and fractions weighed. Data presented in Table C-I show that most of the elutriated particles were < $44 \mu$ or < 325 mesh, the smallest available screen; therefore, a difference in size of elutriated solids from the two types of fuels was not detected. According to these data, the fuel particles from ETR-AI have undergone considerable dissolution and are much smaller than the $\mathrm{COM}-\mathrm{UAl}_{\mathrm{X}}$ powder from which the fuel was made.

\section{DISSOLUTION OF URANIUM ALUMINIDE POWDER}

Dissolutions using the commercial uranium aluminide (COM-UA $I_{x}$ ) were performed to find methods for rapid dissolution of undissolved fuel particles during processing. Reagents were examined for use in process operation and vessel cleanout, and additives were sought which would greatly increase the dissolution rate or catalyze the dissolution of the uranium aluminide in the dissolver. Most dissolutions were performed at $60^{\circ} \mathrm{C}$ so that dissolutions would be reasonably rapid, but slow enough to show the maximum influence of the variables. 


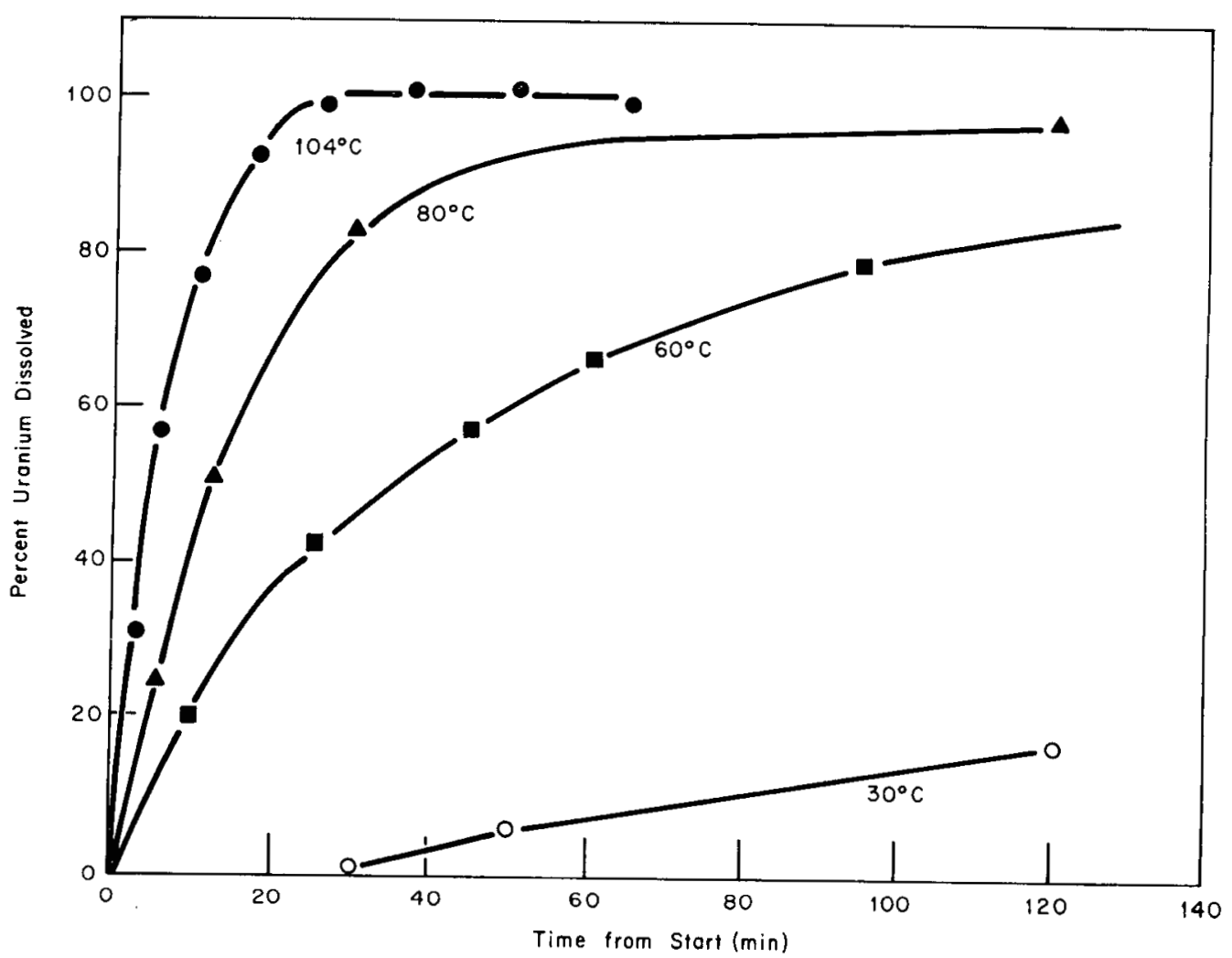

Figure C-1. Dissolution of ${\mathrm{COM}-U A I_{\mathrm{X}}}$ powder.

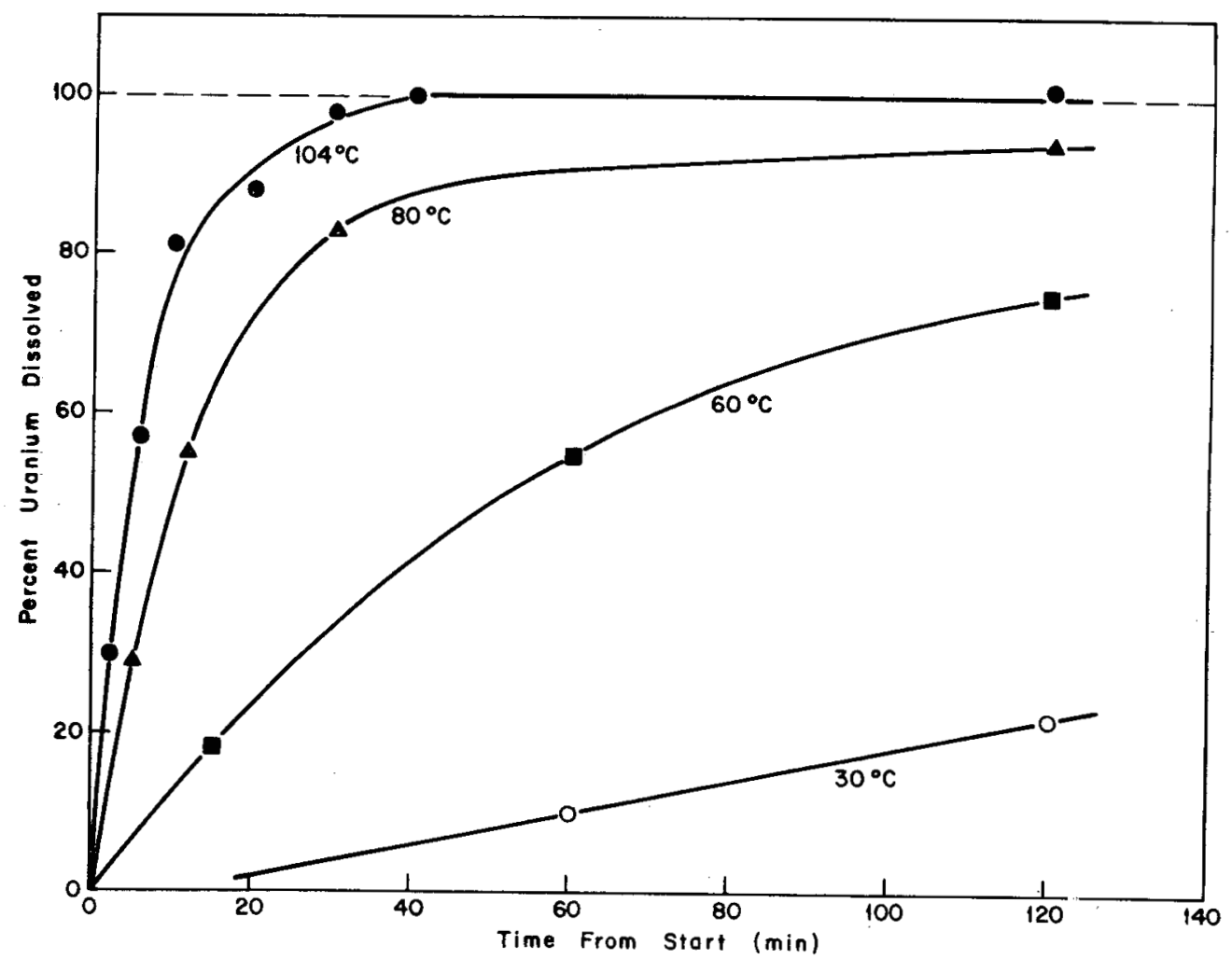

Figure C-2. Dissolution of elutriated solids from ETR-AI fuel. 


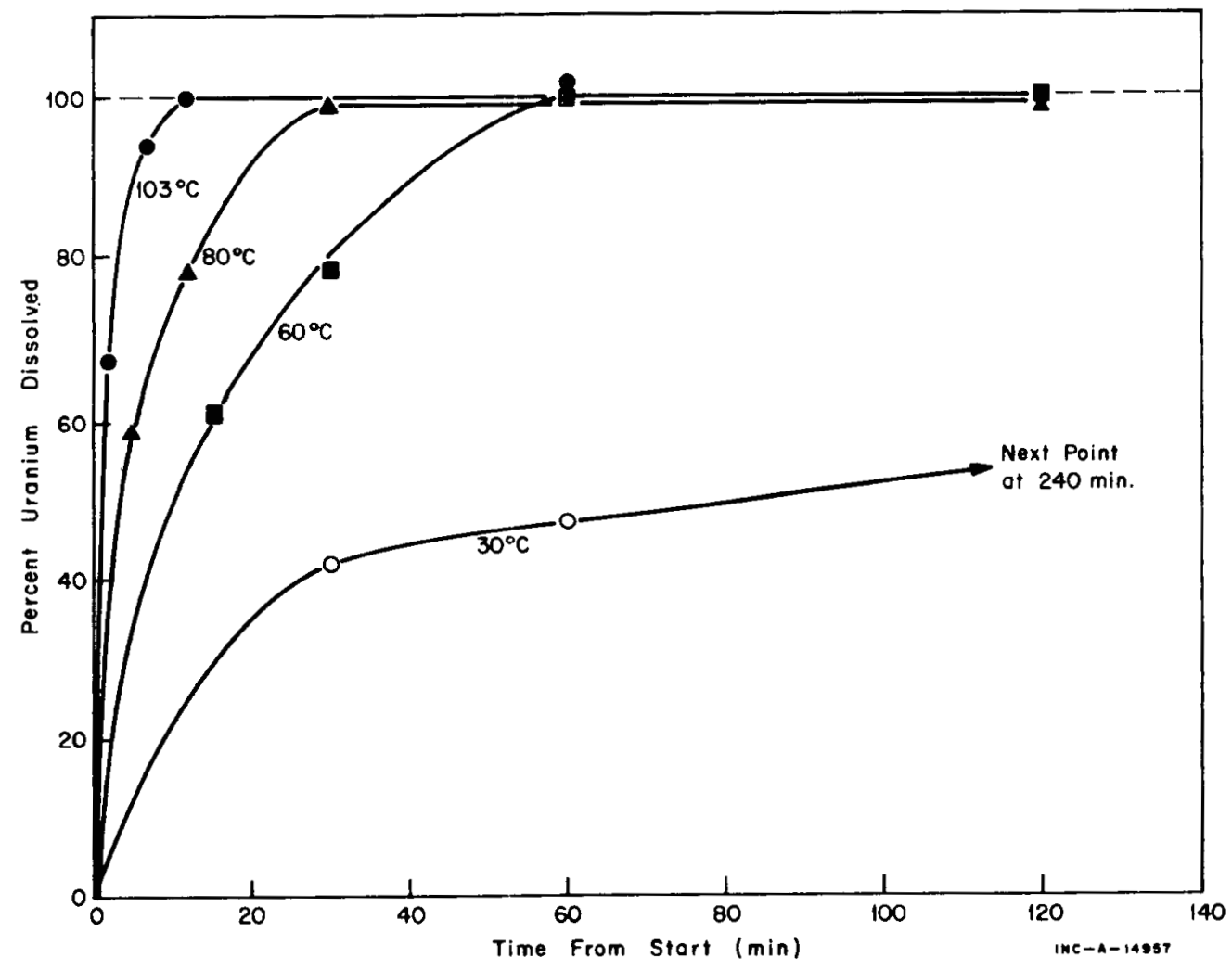

Figure C-3. Dissolution of elutriated solids from ETR-Syl fuel.

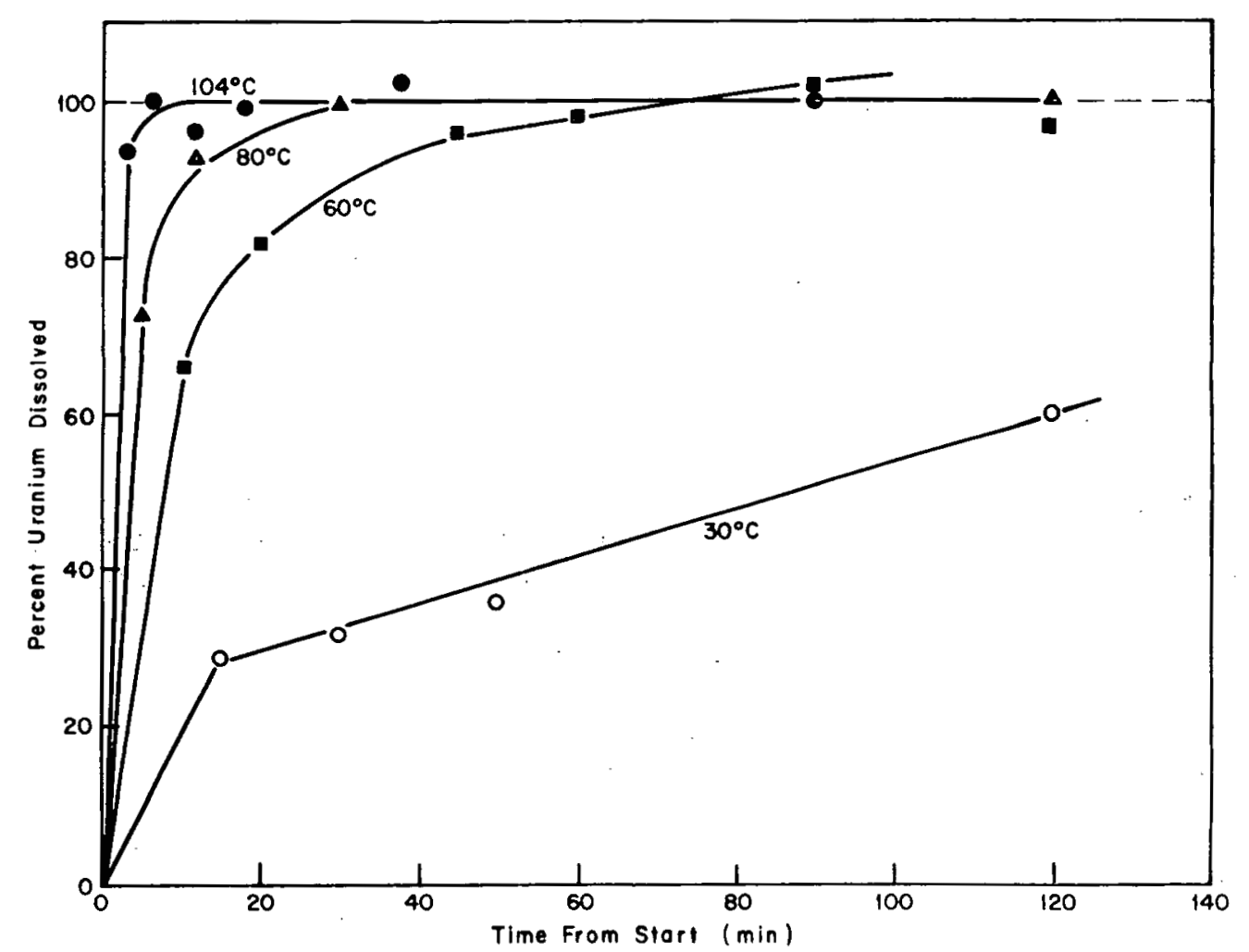

Figure C-4. Dissolution of elutriated solids from ETR-B\&W fuel. 
TABLE C-I.

SIZE DISTRIBUTION OF

URANIUM ALUMINIDE PARTICLES

\begin{tabular}{|c|c|c|c|}
\hline & $\begin{array}{l}-100 \text { mesh } \\
+140 \text { mesh } \\
(105-150 \mu) \\
\end{array}$ & $\begin{array}{l}-140 \text { mesh } \\
+135 \text { mesh } \\
(44-105 \mu) \\
\end{array}$ & $\begin{array}{l}-325 \text { mesh } \\
(<44 \mu) \\
\end{array}$ \\
\hline COM-UA I ${ }_{x}$ Powder & $26 \%$ & $57 \%$ & $17 \%$ \\
\hline Solids from ETR-AI & $1 \%$ & $24 \%$ & $75 \%$ \\
\hline Solids from ETR-Syl & $4 \%$ & $14 \%$ & $82 \%$ \\
\hline
\end{tabular}

\subsection{Reagents for Dissolution}

The best reagent for dissolution of uranium aluminide in process equipment is concentrated nitric acid because the dissolution rate increases with increasing nitric acid concentration and is fairly rapid in $16 \mathrm{M}$ at $30^{\circ} \mathrm{C}$ as shown in Figure $\mathrm{C}-5$. The dissolution of uranium metal also is more rapid at higher nitric acid concentrations, whereas the dissolution rate of aluminum reaches a maximum at 5 to $6 \mathrm{M}$ then decreases at higher acid concentrations. Only $20 \mathrm{wt} \%$ of the uranium dissolved in two hours at $60^{\circ} \mathrm{C}$ in $2.5 \mathrm{M}$ dibasic aluminum nitrate (Diban) which has a $\mathrm{pH}$ of 3.1 .

Mercuric nitrate was not required to catalyze the dissolution in nitric acid as is the case for aluminum. Some increase in dissolution rate did occur as shown in Table C-II, but the effect of the different acid concentrations was much greater. The effect of mercury may be due to the presence of the nitrite ion produced during dissolution of the metal because $0.1 \mathrm{M}$ sodium nitrite sightly increased the rate of dissolution (see Table C-IV). The increase due to addition of mercury is not sufficient to consider as a means of speeding the dissolution of uranium aluminide.

Uranium aluminide was completely insoluble in $3 \mathrm{M}$ sodium hydroxide at $60^{\circ} \mathrm{C}$. The addition of the oxidants, hydrogen peroxide, potassium permanganate and vanadium pentoxide, resulted in partial dissolution, as shown in Table C-III. These data show no promise for a sodium hydroxide dissolution process for uranium-aluminum alloy as the dissolution rates are slower than for nitric acid.

\subsection{Effect of Additives}

Dissolutions were made at $60^{\circ} \mathrm{C}$ using $1.5 \mathrm{M}$ aluminum nitrate and 1.5 M nitric acid to simulate dissolver product solution. Table C-IV presents the concentration of the materials added and the percent of the total uranium dissolved at various times after the addition of the uranium aluminide powder. Although no significant effects were observed, 


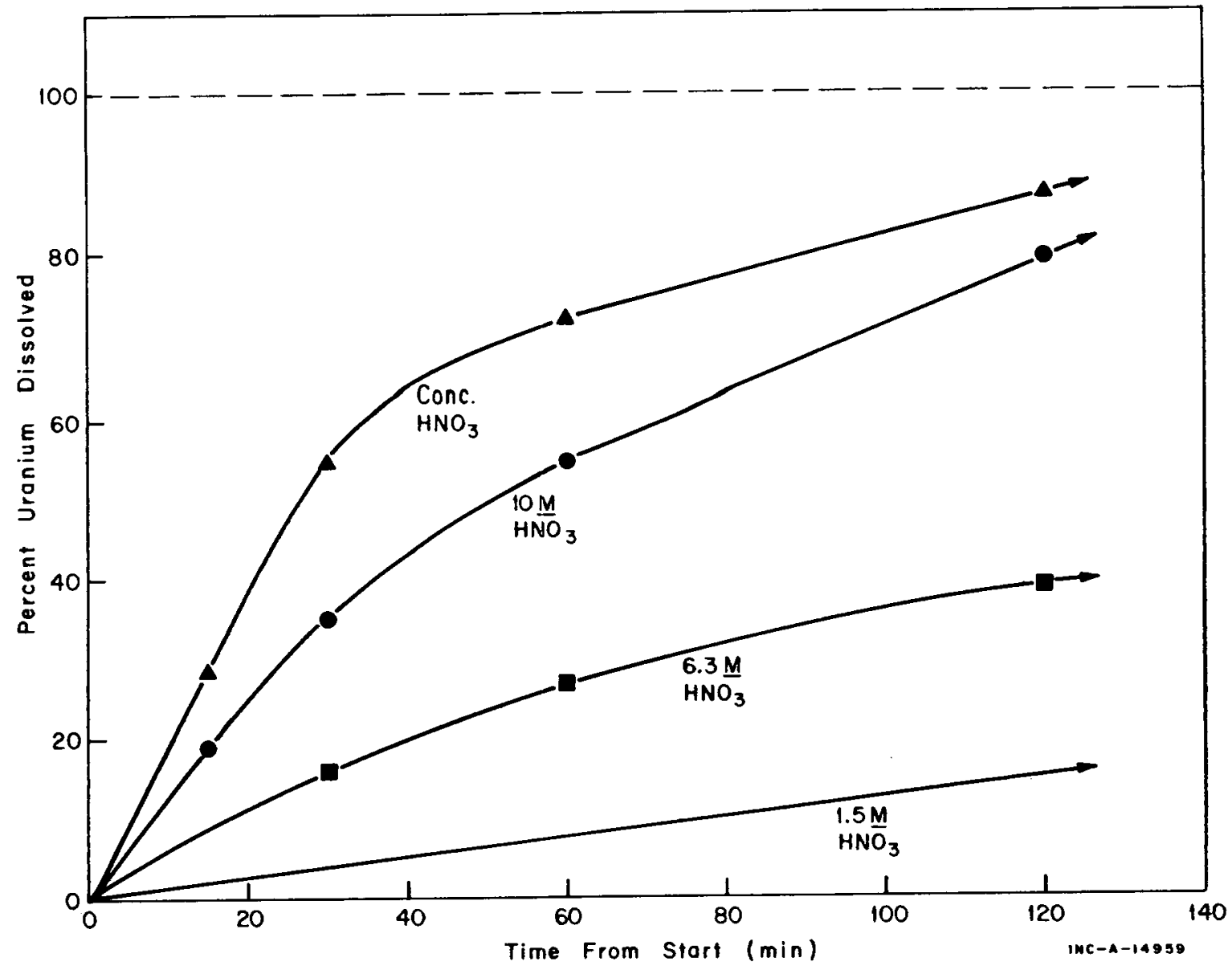

Figure C-5. Effect of nitric acid concentration on dissolution of uranium aluminide $\left(\mathrm{COM}-\mathrm{UA} \perp_{x}\right)$ at $30^{\circ} \mathrm{C}$.

TABLE C-II.

EFFECT OF MERCURY ON DISSOLUTION

OF URANIUM ALUMINIDE AT $60^{\circ} \mathrm{C}$

Percent of Uranium Aluminide Dissolved at Various Times from Start

Solution Composition of Dissolution

\begin{tabular}{|c|c|c|c|c|c|c|}
\hline $\begin{array}{c}\text { Aluminum } \\
\text { Nitrate, M }\end{array}$ & $\begin{array}{l}\text { Nitric } \\
\text { Acid, M }\end{array}$ & $\begin{array}{c}\text { Mercuric } \\
\text { Nitrate, M }\end{array}$ & $15 \mathrm{~min}$ & $30 \mathrm{~min}$ & $60 \mathrm{~min}$ & $120 \mathrm{~min}$ \\
\hline 1.5 & 0.7 & None & 7 & 18 & 32 & 50 \\
\hline 1.5 & 0.7 & 0.007 & 11 & 29 & 48 & 70 \\
\hline 1.5 & 1.5 & None & 22 & 37 & 56 & 77 \\
\hline 1.5 & 1.5 & 0.007 & 29 & 46 & 65 & 84 \\
\hline
\end{tabular}


TABLE C-III.

DISSOLUTION OF URANIUM ALUMINIDE WITH ALKALINE OXIDANTS

Dissolution at $60^{\circ} \mathrm{C}$ in $3 \underline{M} \mathrm{NaOH}$ Solution

\begin{tabular}{|c|c|c|c|c|c|}
\hline Chemical & Additives & \multicolumn{4}{|c|}{$\begin{array}{l}\text { Percent Uranium Aluminide Dissolved at } \\
\text { Various Times from Start of Dissolution }\end{array}$} \\
\hline $\begin{array}{l}\text { Chemical } \\
\text { Added }\end{array}$ & $\begin{array}{l}\text { Concen- } \\
\text { tration }\end{array}$ & $15 \mathrm{~min}$ & $30 \mathrm{~min}$ & $60 \mathrm{~min}$ & $120 \mathrm{~min}$ \\
\hline None & None & 0 & 0 & 0 & 0 \\
\hline $\mathrm{H}_{2} \mathrm{O}_{2}$ & $0.5 \underline{M}$ & 52 & 44 & 56 & 57 \\
\hline $\mathrm{H}_{2} \mathrm{O}_{2}$ & $5 \times 0.1 M^{(a)}$ & 47 & 55 & 57 & 56 \\
\hline $\mathrm{K} \mathrm{MnO}_{4}$ & $0.1 \underline{M}$ & 10 & 11 & 12 & 12 \\
\hline $\mathrm{V}_{2} \mathrm{O}_{5}$ & $0.1 \mathrm{M}$ & 12 & 13 & 14 & 14 \\
\hline
\end{tabular}

(a)

Hydrogen Peroxide was added in 5 portions at 10 minute intervals so as to maintain a minimum of $0.1 M$ throughout the first hour.

there appeared to be slight trends for different types of additives. No effect on dissolution rate was found with fluoride, chloride, sulfate, or phosphate at $0.1 \mathrm{M}$ concentration. The uranium complexers, oxalate and citrate, as well as the oxidants, potassium permanganate and chromic acid, apparently decreased the dissolution rate slightly. A variety of cations were examined because of their effect upon the dissolution of uranium and aluminum. Only silver had a slight positive effect. None of the materials added sufficiently increased the dissolution rate to consider them for process use in the dissolver. 
TABLE C-IV.

EFFECT OF CHEMICAL ADDITIVES ON DISSOUTION OF URANIUM ALUMINIDE Dissolutions at $60^{\circ} \mathrm{C}$ in Dissolver Product

Solutions $\left[1.5 \underline{\mathrm{M} \mathrm{Al}}\left(\mathrm{NO}_{3}\right)_{3}, 1.5 \mathrm{M} \mathrm{HNO}_{3}, 0.007 \mathrm{M} \mathrm{Hg}\left(\mathrm{NO}_{3}\right)_{2}\right]$

Chemical Additives

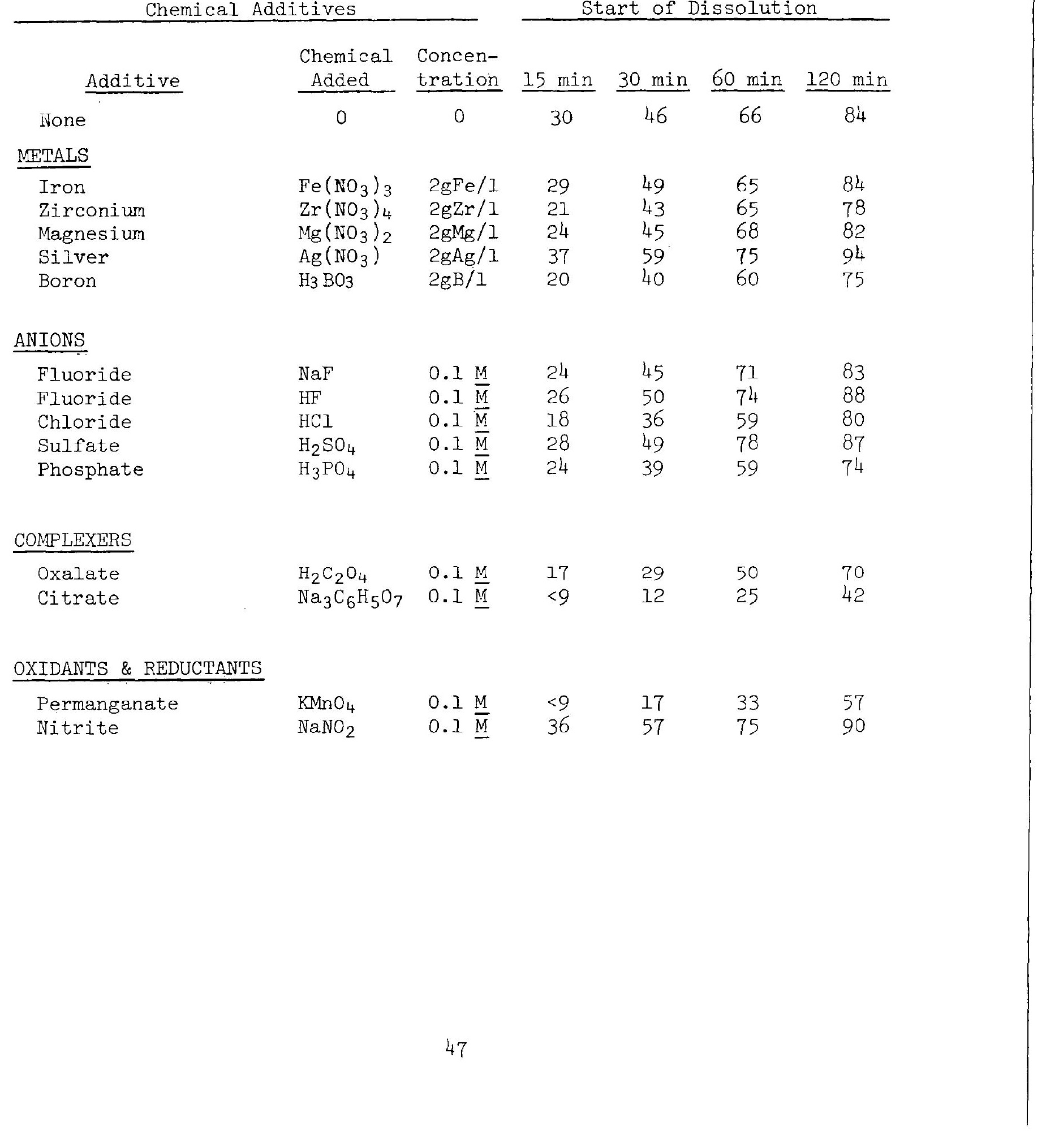
Start of Dissolution

Percent Uranium Aluminide Dissolved at Various Times From 